\title{
Chapter 5 \\ Legal Status, Territorial Confinement, and Transnational Activities of Senegalese Migrants in France, Italy, and Spain
}

Migrants have long maintained ongoing social, economic, and political connections with their homelands, but these transnational activities have garnered increased attention from scholars and policymakers in recent years. Academic research has shown that modern travel and communications technologies have created new kinds and quantities of transnational engagement, findings which have challenged the notions of the state control of borders and of unidirectional immigrant settlement and assimilation. At the same time, international development agencies and sending-country governments have begun to recognize the potential of migrants to be active participants in the development of their home communities. Such "co-development" strategies seek to leverage migrant cross-border activities, such as remittances, investment, and participation in hometown associations, as part of overall development strategies.

Such celebrations of immigrant transnationalism ignore the constraint that irregular legal status may place on cross-border engagement. While much research on transnationalism argues that these activities transgress and subvert the state's ability to control cross-border flows, scholars have generally not been attentive to the sensitivity of different kinds of cross-border action to robust immigration-control apparatuses. Transnational activities that are mobile-such as visits to the homeland-may be more directly structured by legal-status constraints than non-mobile activities such as remitting. Furthermore, studies recognize occasional physical visits to the homeland to be an important component of the transnational social field, both as an important link between destination and origin in its own right and as a crucial way to maintain the affective links that sustain non-mobile activities such as remitting and investing. Yet most research does not consider the direct constraint on

\footnotetext{
The original version of this chapter was revised: Footnote was inserted in the chapter opening page. The correction to this chapter is available at https://doi.org/10.1007/978-3-030-12088-7_7

Portions of Chapter 5 were previously published as: Vickstrom, E. R., \& Beauchemin, C. (2016). Irregular status, territorial confinement, and blocked transnationalism: Legal constraints on circulation and remittances of Senegalese migrants in France, Italy, and Spain. Comparative Migration Studies, 4(1), 1-29. https://doi.org/10.1186/s40878-016-0037-8.
} 
physical mobility faced by migrants without secure legal status or the effect that such reduction in mobility might have for non-mobile, long-distance activities. Nor do policy prescriptions for co-development, which actively promote migrant crossborder engagement, factor in the contradictory state policies that lead to the legal confinement and subsequent reduced transnational participation of migrants.

This chapter explores the link between legal status and transnational activities through the lenses of territorial confinement and blocked transnationalism. It hypothesizes that irregular legal status results both in direct territorial confinement-an inability to visit the homeland - and in indirect caging of non-mobile transnational activities. This caging is hypothesized to result from the withering of affective ties associated with reduced physical co-presence with kin and other important individuals in the homeland from which migrants often draw their sense of status. The chapter also explores the constraint of irregular status on non-mobile transnational activities through structural exclusion from institutions in the destination country.

Senegalese migrants in France, Italy, and Spain provide the empirical data on which these hypotheses are tested. Senegalese migrants are renowned in the qualitative literature for practicing "transnational livelihoods" predicated on circulation between the destination and the homeland and the accumulation of material wealth and social status in Senegal in preparation for an eventual return. At the same time, Senegalese migrants often lack secure legal status: those without "papers" are often "stuck" in the destination country and may thus face challenges in constructing a transnational existence. Thus the development potential of this group of migrantslauded by the French and Spanish government and coveted by the Senegalese state - may be short circuited by lack of secure legal status.

The chapter is organized as follows. The next section reviews the literature on transnational activities and suggests that scholars of transnationalism have largely overlooked both the physical confinement resulting from irregular status and the indirect effect of this confinement on non-mobile activities. The chapter then presents some qualitative evidence on the transnational participation of Senegalese migrants. The following section describes the data and methods for the empirical analysis. The results confirm that irregular status is negatively associated with short visits to the homeland, resulting in a territorial confinement that is transmitted to the non-mobile activities of remitting and investing. Discussion of the findings follow and a final section concludes.

\subsection{Types of Transnational Activities}

Since the early 1990s, the concepts of migrant transnational activities—social, economic, cultural, and political actions that migrants living abroad carry out in their home country - and migrant transnationalism - the condition of being that accompanies such cross-border action - have ridden a theoretical and empirical rollercoaster in the social sciences. Researchers initially hailed the concepts as a novel lens for understanding the lived bifocal realities of migrants in advanced postindustrial economies, with advances in transportation and communications technologies making it possible 
for these migrants to live their lives simultaneously in destination and sending countries (Glick Schiller et al. 1995; Portes et al. 1999). Subsequent research has sought to distinguish migrant from other types of transnationalism but also questioned the novelty, normativity, scope, and liberatory potential of the phenomenon (Foner 1997; Waldinger and Fitzgerald 2004). The current consensus is that, while transnational activities are neither novel nor practiced by all immigrants everywhere, the concept still serves as an important conceptual lens for understanding a distinct path of immigrant incorporation (Portes 2010): immigrants are no longer limited by the social, cultural, economic, and political opportunities offered to them by their new host societies but can draw on cross-border ties to conduct their lives transnationally.

With the recognition that transnational engagement is neither widespread nor normative has come an insistence on the heterogeneity of transnational practices. Migrants' activities linking receiving and sending areas can take on a variety of forms, and researchers have commonly arranged them according to the typology of economic, political, and sociocultural transnational activities (Boccagni 2012b; Itzigsohn and Saucedo 2002; Portes et al. 1999). Economic transnational activities include sending monetary and in-kind remittances, investments in property or businesses in the homeland, circular labor migration, and informal cross-border trading enterprises. Political transnational activities include distance voting, the exercise of dual citizenship, fundraising or other support in the destination for candidates in the homeland, and even running for and holding office in the homeland while residing abroad. Sociocultural transnational activities can include visits or "systematic communication a distance" with family members and friends in the homeland, organization of homeland-oriented cultural activities abroad, and participation in civic, recreational, or solidarity initiatives. Some scholars also classify participating in hometown associations (HTAs) as a political activity given the influence they can have on local power dynamics in the hometown (Portes et al. 1999). Research has thus shown that a wide variety of kinds of activities make up the transnational social space.

\subsection{The Role of the State in Migrant Transnational Activities}

Following Portes et al.'s (1999) call to delimit the phenomenon of transnationalism empirically, the last decade has seen a flowering of studies of a myriad of kinds of transnational activities among a wide variety of groups (for a review, see Levitt and Jaworsky 2007). Research has also focused on the determinants of cross-border social action. Many studies have shown that individual characteristics such as age, education, occupation, and length of residence in the host community are associated with a variety of transnational activities, and scholars have concluded that engaging in sustained interaction with the homeland is not a threat to migrants' successful integration in the destination society (Guarnizo 2003; Guarnizo et al. 2003; Itzigsohn and Saucedo 2002).

What has been missing from this literature, however, is an examination of how state immigration-control apparatuses and the legal statuses they produce (see Chap. 2) may also structure transnational activities. Given the widespread acknowledgement 
of the preponderant role that legal status plays in the incorporation of migrants in the destination society (Massey 2007; Portes and Rumbaut 2006), it is surprising that scholars have paid so little attention to the impact that legal status may have on the transnational activities that have been shown to accompany such integration.

This oversight may be due, in part, to a tension in the transnational-studies literature regarding the conceptualization of the role of the state. Much of the early literature on migrant transnational activities focused on the subversive character of these activities vis-à-vis national borders. Transnational activities explicitly take place across borders and seemingly despite state attempts at control, and some scholars found the very fact of subverting a border to be a sign of the weakness or even inability of the state to control flows of people, money, ideas, and values (Glick Schiller et al. 1995).

In this view, the state and its territorial border-and the national membership that this frontier implies-are unable to contain the globe-spanning networks that "transmigrants" construct via their incessant physical, social, and economic connections to the homeland. These connections, it is argued, are possible mainly because of technological advances in travel and communications that compress time and space: jumbo jets make formerly insurmountable distances between destination and origin easily traveled, and mobile phones and the internet allow migrants to be in daily touch with their families in the homeland (Vertovec 2003). While subsequent historical work has questioned the argument that cross-border engagement is a novel form of social action (Foner 1997), new technologies have made these activities easier and cheaper, and have thus had an impact on the quantity and kinds of cross-border engagement (Portes et al. 2002).

Despite the assertion that technologically advanced migration transnational activities indicate a diminished ability of national borders to contain migrant transnational activities, there are reasons to be skeptical of pronouncements of the demise of the state. While technology and its democratization are certainly necessary conditions for current transnational activities (Portes et al. 1999), the same technology that facilitates the flows of people, money, and ideas in the current globalized world has also undoubtedly led to increased state immigration-control capacities. As Zolberg's work demonstrates for the US, migration-control apparatuses have long kept pace with advances in technology: the American government introduced a system of "remote control" of immigration in the nineteenth century through its requirement of passports and visas and concomitant network of overseas consulates, and was successfully able to screen out potential immigrants that it deemed "undesirable" (Zolberg 1999). The role of technology is well documented in contemporary border control: the governments of the US and Europe have spent massive sums of money to increase surveillance along their southern borders (Carling 2007; Massey et al. 2002). Governments have also introduced biometric visas and identity documents and electronic document verification systems for immigrant workers. The technology that has created the conditions for transnational activities has thus also created the possibility of increased control of those flows.

Research has also shown, however, that the technological ability to control migration flows is a necessary but not sufficient condition for such control, as it 
must be coupled with political will to instill and enforce such systems. Formal systems of immigration control are often compromised by special interests, allowing unauthorized flows to continue through "back doors" for reasons of political and economic expediency (Freeman 1995; Zolberg 1999). State immigration-control capacity is thus often variable, contested, and contingent on a variety of economic and political factors. The existence of transnational flows does not necessarily call into question the ability of the state to contain such flows.

Indeed, recent research has argued that the state needs to be "brought back in" to the study of transnational activities. Waldinger (2008) argues that international migrants have and will always participate in the kind of cross-border activities celebrated as transnational; what is missing in the analysis, he argues, is analysis of the ability of the state and its borders to bound both identificational and territorial belonging. States and their efforts to control borders can act to "cage" migrants, both through processes of settlement and territorial confinement. The identificational demands of modern nation-states encourage legally resident migrants with an initially transnational orientation to abandon it in favor of identification with the destination polity.

For those migrants not legally part of the national group, state efforts to control movement across borders effectively confine them to the territory of the destination country; this constraint on physical mobility entails the progressive withering of the social ties that nourish cross-border engagement (Waldinger 2008). Waldinger (2008) describes this process as "double capture" in which the destination state constrains the cross-border engagement of both documented and undocumented migrants. Thus, the state not only has an impact on transnational activities in ways that run counter to the subversive description of migrant transnationalism, but its efforts to police its borders and ensure social closure are of primary importance for the ability of migrants to engage in these activities. Indeed, scholars have begun calling for approaches to transnationalism that grapple with the political and legal constraints on mobility (Boccagni 2012b; Mountz et al. 2002).

\subsection{Homeland Visits and Territorial Confinement of Migrants with Irregular Status}

How does the legal reality of the state, its borders, and the concomitant legal statuses constrain the cross-border actions of migrants? The answer to that question depends, in part, on the action under consideration. Some transnational activities may be more sensitive to legal reality than others, especially those that depend in some way on migrants having a secure legal status in the destination society. The most relevant example is travel between destination and origin. While this kind of travel is certainly much easier, cheaper, and quicker in the contemporary world than before, destination states are also more technologically capable of restricting movements across their borders. As Waldinger (2008) points out, migrants do not come 
and go as they please, but only engage in physical cross-border mobility to the extent that states allow it.

Legal status is clearly the key factor in allowing migrants to travel freely between destination and their home communities: those migrants who lack secure legal status are less likely to engage in this kind of circulation because they are not guaranteed re-entry and do not want to risk the cost and potential danger of an unauthorized entry (Massey et al. 2002).Empirical research bears out the relationship between legal status and circulation. Kaag (2008) finds that Senegalese migrants in Italy without "papers" describe themselves as being "stuck" because they do not want to expose themselves to the cost and risk of an additional irregular passage. Waldinger (2008) finds that homeland visits are the most common form of cross-border activity among his sample of Colombians, Cubans, Dominicans, and Salvadorans, but he also finds that secure legal status strongly predicts the probability of travel home. Immigration policies and politics are thus a crucial conditioning factor for this form of cross-border engagement: migrants who lack secure legal status experience a "territorial confinement" (Waldinger 2008) that constrains their movement across the national border. We would thus expect a direct negative effect of irregular legal status on Senegalese migrants' propensity to return home for short visits because of the political barrier to mobility inherent in irregular status.

\subsection{Blocked Transnationalism and Structural Exclusion}

While the constraint that legal reality places on physical circulation between destination and origin is unambiguous, the link between legal status and cross-border action is less clear for other transnational activities. Why would irregular legal status constrain remittances, investments, or participation in associations? The literature provides some answers in the form of the concepts of blocked transnationalism and structural exclusion. Restrictive immigration-control policies are a negative feature of the context of reception that can block transnational ties with the home country (Portes and Rumbaut 2006). This blocked transnationalism manifests itself in the structural exclusion of migrants with irregular status from various formal institutions in the destination society (Bloch 2008; Mazzucato 2008; Van Meeteren 2012).

Lack of legal status can, for example, prevent migrants from participating in the formal labor market, relegating them to informal, precarious, and low-paid jobs; this insecurity could make them less likely to have the means to participate in transnational activities. Lack of legal status could also constrain participation in various financial institutions: not having a bank account or not being able to access credit could reduce migrants' abilities to send remittances to and invest in assets in Senegal, for example. Structural exclusion could thus be considered an indirect effect of irregular legal status: the direct constraint of insecure legal status is on migrants' ability to participate in formal institutions, which in turn limits migrants' transnational engagement; lacking data on this kind of participation, then, legal 
status can act as a proxy for this kind of structural exclusion. We would thus expect a direct negative effect of irregular legal statuses on remitting, investing, and participating in HTAs because of blocked transnationalism and the structural exclusion it engenders.

\subsection{Affective Ties, Homeland Visits, and Non-mobile Transnational Activities}

The negative effect of territorial confinement on circulation between destination and origin coupled with research that strongly demonstrate the importance of affective ties and physical co-presence for ongoing transnational engagement together suggest a negative indirect effect of irregular status on long-distance, non-mobile transnational activities functioning through the withering of social ties. The territorial confinement and structural exclusion hypotheses both posit a negative effect of irregular legal statuses on Senegalese migrants' cross-border activities: irregular status simultaneously constrains migrants' abilities to cross the destination state's borders and to participate in formal institutions that promote other forms of crossborder engagement. The constraint that the legal reality imposes thus depends on the kind of activity and whether that activity involves the physical crossing of a border. The literature suggests, however, that occasional physical border-crossing itself may be vitally related to the ability of migrants to maintain the social ties that underlie continued long-distance transnational activities. If lack of secure legal status constrains visits to the homeland, this constraint could be transmitted to longdistance, non-mobile activities by the weakening of social ties.

What is it about visits home that might encourage other kinds of transnational engagement? Studies of transnationalism often assert that advances in communications technologies have rendered physical distance, and the need for physical copresence, obsolete (Diminescu 2008). Virtual co-presence, in this view, substitutes effectively for physical co-presence in nourishing the social links that motivate and sustain regular cross-border social engagement. While scholars of mobility have recognized the potential for communications technologies to compress space and time in novel ways, there is still some doubt as to the ability of virtual communication to replace physical face-to-face interactions (Boccagni 2012a).

Mobility research has found, for example, that interactions involving physical co-presence are necessary for developing extended relations of trust (Urry 2002). Indeed, even communications at a distance, while allowing some maintenance of social ties, actually increase the need to reinvigorate these relationships via occasional physical co-presence (Boccagni 2012a; Urry 2002). Physical visits to the homeland allow migrants to build and renew the trust and emotional identification that underlie long-distance social ties. In a more instrumental sense, they also allow migrants to gather first-hand information on the wellbeing of their families, the suitability of business opportunities and partners, and the overall socioeconomic 
conditions of their communities and could thus inform decisions to send money, invest in assets, and participate in collective development efforts.

The findings of studies of transnationalism literature suggest that cross-border activities are responsive to affective ties between migrants and their origin communities. Itzigsohn and Saucedo (2002) find that the maintenance of emotional and affective ties-what they call "linear transnationalism" - is an important predictor of sociocultural cross-border engagement. These affective connections are evident in other research on other kinds of transnational activities. Landolt et al. (1999: 312) argue that Salvadoran household-level transnational activities are motivated by "a deep sense of obligation" on the part of the immigrant. Guarnizo et al. (2003) find that the expectation that migrants return to their home communities is a strong predictor of transnational political engagement.

Sana's (2005) findings that remittances are motivated by status loss and discrimination at destination also indicate that migrants continue to see the home community as their valid reference group and draw their self-worth from home-community value systems. Ongoing social ties are also important for the maintenance of transnational engagement: Bloch's study of Zimbabweans in the UK shows that kinship ties and staying in touch with family in the origin community are important determinants of remitting. The common finding that married males have a high propensity for transnational activities (Guarnizo et al. 2003; Itzigsohn and Saucedo 2002) also reflects contexts of exit from which men migrate more often than women and in which migration may be a family survival strategy.

Affective ties to kin play a large role in structuring the transnational activities of Senegalese migrants. Riccio (2008) argues that the family is the mainstay of social organization for Senegalese both at home and abroad. Organized around communalism and a hierarchical structured solidarity, the family remains a durable social institution in Senegal (Beauchemin et al. 2013). Furthermore, emigration from Senegal is largely a family strategy, as migration is pursued by individual men with assistance from kin, and a desire to return home leads to a temporary socially expected duration of migration on the part of both the migrant and the family (Riccio 2008). The family is the main source of status for Senegalese migrants, and this connection precludes many migrants from constructing families or pursuing family reunification at destination (Beauchemin et al. 2013; Riccio 2008). Kane (2011) argues that these kinds of affective ties are crucial to Senegalese transnationalism: Senegalese migrants living abroad engage in transnational activities as a way to seek status from their contributions to their family in the homeland, often in preparation for an eventual return.

Other studies of transnationalism state that physical circulation between destination and origin is important in facilitating other transnational activities in instrumental, rather than affective, ways. Qualitative work has shown the importance of mobility for transnational political participation: Smith (2006) recounts that Mexican members of the Ticuani Solidarity Committee of New York would travel to Ticuani to consult with authorities and contractors on committee-funded public works projects over the weekend and would be back in New York in time for work on Monday morning. Riccio (2001) describes a similar situation for Senegalese 
migrants, who engage in what he calls "transnational livelihoods" that involve frequent trips back to Senegal to facilitate investments and other business dealings. Quantitative work often assumes the importance of cross-border travel but leaves it unanalyzed. Portes and associates (Portes et al. 2002; Portes and Zhou 2012) assert that transnational entrepreneurship is at least partially dependent on the ability to be physically present both "here" and "there," but the actual practice of short visits to the homeland is not included as a predictor variable in models. Waldinger (2008) analyzes the regularity and recency of home-country travel, but does not directly examine its effect on other cross-border activities.

Occasional physical presence in the homeland is thus of clear importance for the maintenance of affective social ties and the instrumental gathering of information, which are themselves the crucial social infrastructure of trasnational flows. The strand of transnational studies that celebrates the ability of new communications technologies to compress time and space in such a way as to allow ongoing crossborder activities thus excludes a potentially important determinant of such activities by minimizing the importance of physical travel between destination and the homeland. We would thus expect a positive direct effect of short returns on non-mobile transnational activities, such as remitting, investing, and participating in HTAs.

\subsection{Caging Non-mobile Transnational Activities}

A relationship between short visits to the origin community and other transnational activities opens the door to an important indirect effect of irregular legal statuses on cross-border engagement that does not directly depend on the physical crossing of borders (henceforth referred to as "non-mobile transnational activities"). Waldinger (2008) argues that states effectively "cage" migrants with irregular legal status by constraining their movement across borders. This caging not only limits their physical movement but also, by limiting physical co-presence with important people "back home," constrains their social ties to the homeland. Short returns home thus act as a mediator of irregular legal statuses. If migrants with irregular legal status experience territorial confinement that constrains their ability to circulate, and if short visits to the homeland allow migrants to maintain affective ties and gather information, and if these ties and information encourage migrants to participate in other forms of cross-border action, then migrants with irregular legal status should participate less in those forms of cross-border action that depend in some way on physical presence in the homeland.

While the literature is suggestive of this indirect effect of irregular legal status on non-mobile transnational activities, few studies have simultaneously examined the direct relationship between short returns and non-mobile transnational activities and the indirect relationship between irregular legal status and non-mobile transnational activities transmitted via inhibited cross-border mobility. Waldinger (2008: 24) notes that "better settled migrants with secure legal status are more likely to engage in activities requiring physical presence in the homeland," but he does not examine 
the impact that migrants' legal status has on both physical presence in the homeland and the activities that require such presence. This impels us to examine this indirect link and to hypothesize that irregular legal status will indirectly constrain nonmobile transnational activities. Senegalese migrants who do not have the ability to circulate between destination and origin because of their irregular legal status are effectively prevented from engaging in transnational livelihoods that depend on this circulation.

\subsection{Transnational Activities of Senegalese Migrants}

Senegalese migrants in Europe and across the globe have been noted for their regular and sustained participation in the lives of the kin and communities they left behind in their homeland. Studies of Senegalese migrants have argued that they live their lives across borders in multiple places simultaneously and that the dominant mode of organization of their migration experience is transnational (Kane 2011) with an overriding goal of creating economic, social, and spiritual lives in Senegal to which they hope to return (Riccio 2008). Indeed, Senegalese are quite active in a number of transnational spheres. Official monetary remittances to Senegal tripled between 2002 and 2008, rising from $\$ 305$ million to $\$ 1.2$ billion (Cisse 2011); and while the financial crisis of 2008 took its toll, estimates for 2017 still place official remittances at $\$ 2.3$ billion, or about 10\% of GDP (World Bank Group 2016, 2017).

In terms of the absolute value of remittance flows, Senegal ranks third in subSaharan Africa, behind only demographic giants Nigeria, and Ghana (World Bank Group 2016). In addition, official remittances are thought to make up only 54\% of total remittances. Research has highlighted the impacts of these monetary flows in Senegal at the household and macroeconomic level: remittances reduced poverty nation-wide by $30 \%$, and accounted for a large portion of national macroeconomic accounting, ahead of both foreign direct investment and official development assistance and equal to about $40 \%$ of export earnings (Cisse 2011).

The transnational activities of Senegalese migrants are not limited to remittances. Short visits to Senegal by migrants residing abroad are an integral part of what Kaag (2008) calls a "circular transnational livelihood," facilitating trade and other economic transactions (Riccio 2008). Recent quantitative work on Senegalese migration has shown that Senegalese are more likely than Ghanaians or Congolese to make visits to their home country: half of Senegalese migrants visit Senegal within 5 years of departure, while only a third of Ghanaians and $10 \%$ of Congolese do so (Schoumaker et al. 2013). Tall (2008) argues that urban migrants have invested a large proportion of their foreign earnings in real estate, and that these visible (and occasionally ostentatious) signs of success have played a large role in creating a "culture of migration" that sustains a transnational social field and quantitative research has recently found Senegalese migrants to have a high propensity to invest in Senegal (Schoumaker et al. 2013). 
Senegalese migrants also participate in a variety of transnational associations, which collect funds from migrants to promote construction of schools, health centers, roads, irrigation systems, and places of worship in their villages or hometowns, in addition to providing moral and financial support to co-national migrants at destination (Grillo and Riccio 2004; Kothari 2008). Their families also tend to be transnational: family reunification is lower among Senegalese migrants than among other African migrants in Europe, with spouses commonly remaining in Senegal (Schoumaker et al. 2013; Hannaford 2017). Senegalese migrants thus participate in a wide variety of transnational activities, lending credence to the assertion that they organize their migration strategies along transnational lines.

Despite the apparent ubiquity of transnational engagement among Senegalese migrants, studies have also demonstrated that these migrants' cross-border activities are constrained by their lack of secure legal status. Senegalese migrants without residence papers are "stuck" in their destination (Kaag 2008; Kane 2011): they do not have the legal ability to cross the border that separates them from their homeland. Riccio $(2001,2008)$ highlights the important role that acquisition of the permesso di soggiorno plays for Senegalese migrants in Italy: without it, they are not able to practice the circular transnational livelihoods that purportedly mark the Senegalese migration experience.

Lack of legal status constrains the mobile and non-mobile transnational activities of Senegalese migrants. This constraint is all the more important given the oftenprecarious legal situation in which Senegalese migrants in Europe find themselves (see Chap. 3 for an examination of the pathways into irregular status among Senegalese migrants). Senegalese have long been suspected of participating in "clandestine" or irregular migration strategies in Europe. Senegalese migrants were targets as "false tourists" in France during the late 1960s (Diop 1993; Spire 2005) and were publicly visible in the sans papiers movement in the 1990s (Timera 1997). Senegalese in Italy and Spain may have first entered these destinations in a quest for legal status through regularization programs and remain among the nationalities with the highest rates of irregularity.

This chapter explores the link between legal status and the transnational activities of Senegalese migrants in France, Italy, and Spain. While there is a voluminous research literature on the cross-border activities of migrants, few of these studies focus explicitly on the impact of migrants' legal statuses on their transnational engagement (Van Meeteren 2012). When the literature does mention legal status, it either simply assumes that irregular migrants are excluded from cross-border activities or finds that they are somehow structurally excluded without examining how this exclusion happens. Much of this lack of recognition of the role of legal status could be due to the apparent lack of a direct link between legal exclusion and crossborder participation. Many researchers may concur with Sciortino, who argues that "[1]egal status is significant, indeed relevant, only when and if - and to the degree to which - the legal reality is a constraint over the relationships and actions of the actor" (2004: 22) and assume that the legal reality is not a constraint over transnational action. This chapter explicitly examines the extent to which the legal reality is a constraint over this kind of action among Senegalese migrants in Europe. 


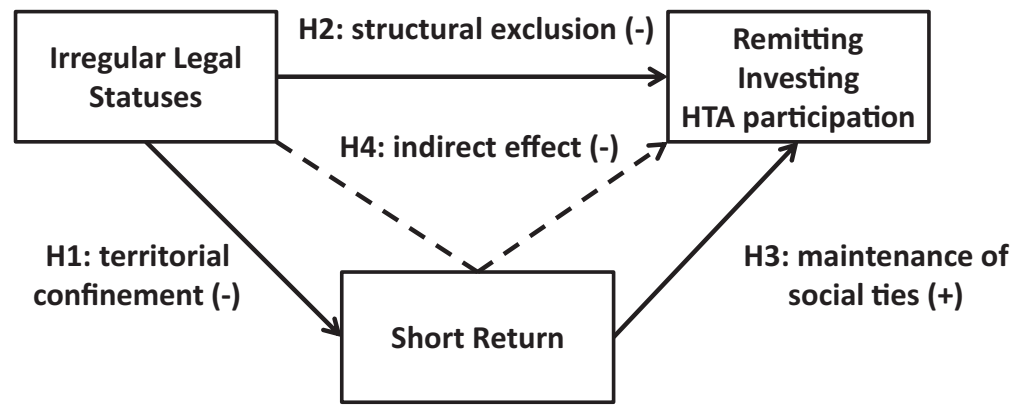

Fig. 5.1 Hypothesized relationships between irregular legal status and transnational activities

\subsection{Hypotheses}

Figure 5.1 summarizes the hypothesized relationships between irregular legal status and Senegalese migrants' cross-border engagement. The territorial confinement hypothesis (H1) posits a direct legal constraint of irregular status on migrants' short returns to Senegal. The structural exclusion (H2) hypothesis postulates a direct legal constraint of irregular status on migrants' abilities to participate in formal institutions that may promote non-mobile cross-border engagement; irregular status is thus a proxy for unmeasured blockages of participation in such institutions. The affective ties (H3) hypothesis suggests a link between short returns and non-mobile transnational activities - remitting, investing, and participation in hometown associations_-via the maintenance of affective links and the ability to gather first-hand information through occasional physical presence in the homeland. Finally, the caging hypothesis ( $\mathrm{H} 4)$ posits that the territorial confinement of migrants with irregular statuses (H1) constrains social ties with the homeland (H3) in a way that dampens non-mobile cross-border activities. The legal reality thus constrains cross-border action in a multitude of direct and indirect ways that depend, in part, on the crossing of physical and institutional borders.

\subsection{Data and Methods}

\subsubsection{Data Source}

The analyses performed in this chapter rely on a data from the Migration between Africa and Europe (MAFE-Senegal) project. While Chap. 1 describes the MAFE project in detail, this section highlights some additional features of the data that are pertinent for this chapter's analyses. The multi-sited character of the MAFE data avoids potential biases in the retrospective measurement of transnational activities by including individuals who have returned to Senegal after a stay in Europe. 
Furthermore, the inclusion of three different countries allows study of the extent to which transnational practices vary according to the context of reception, especially in relation to varying policy contexts regarding legal status. The retrospective nature of the data allows longitudinal and time-varying analyses, which are important as both legal status and transnational participation are likely to vary from year to year over a migrant's stay at destination.

\subsubsection{The Analytic Sample}

All person-years during which an individual was a migrant in France, Italy, or Spain contribute to this chapter's analyses. The sample thus includes person-years contributed by return migrants in Senegal who spent time in one or more of the three European countries. Migrants interviewed in any of the European countries may also contribute person-years to the analysis of other countries if they previously spent time in those countries (i.e., migrants can have more than one trip). The total analytic sample comprises 658 individuals contributing 8188 person-years. The French subsample contains 264 individuals and 3677 person-years, the Italian subsample contains 200 individuals and 2413 person-years, and the Spanish subsample comprises 198 individuals and 2098 person-years.

\subsubsection{Outcome Variables}

Modules of the MAFE biographical questionnaire gathered information on migrants' transnational practices, including short returns to Senegal, remittances, investments, and participation in associations (see Appendix B for the wording of the questions). The outcome variables in this chapter are four separate time-varying indicators of four types of transnational activities among Senegalese migrants in France, Italy, and Spain.

For short returns, the interviewer asked migrants in which year(s) they returned to Senegal while living abroad. A dichotomous variable indicates a short return to Senegal for each year in which a visit took place (with " 1 " indicating a visit and "0" indicating no visit).

For remittances, the interviewer asked if the individual regularly sent money to someone who lived in a different country, and, if so, during which periods and to which country. A dichotomous variable indicates remittances to individuals in Senegal for each year in which a migrant reported sending money to someone living there (with " 1 " indicating remitting and " 0 " indicating no remitting). This variable captures the directionality and regularity of remittances, but not the amount remitted.

Investments were measured by asking individuals if they had ever owned (through gifting, inheritance, or purchase) assets in Senegal or elsewhere, and if so, 
when they owned the asset. A dichotomous variable indicates ownership of at least one asset in Senegal purchased while the migrant lived abroad for each year in which a migrant reported owning an asset there (with "1" indicating ownership and " 0 " indicating no ownership). This variable excludes inheritances or gifts.

For hometown associations (HTAs), migrants indicated the years during which they participated financially, via contributions or membership fees, in associations that finance projects in Senegal or support Senegalese migrants in Europe. A dichotomous variable indicates HTA participation for each year in which a migrant contributes to such associations (with " 1 " indicating participation and " 0 " indicating no participation).

\subsubsection{Predictor Variables}

The main predictor variable of interest is the contexts of reception faced by Senegalese migrants is their legal status. As described in Chap. 3, administrative histories in the MAFE questionnaire provided information on migrants' statuses in the legal domains of entry, residence, and work authorization. This chapter uses the typology of legal statuses developed in Chap. 3. This typology includes indicators of entry status and yearly combined residence and work authorizations. A dichotomous variable indicates entry status as visa $(\mathrm{V})$ or no visa $(\mathrm{NV})$ based on migrants' responses about whether or not they had a visa when they entered the destination country; this variable is thus defined for the year of arrival for each trip. A composite categorical variable indicates legal status in each year during the migrant's residence in a destination: RP_WP ("fully regular status"), NRP_WP ("mixed status, no residence permit"), RP_NWP ("mixed status, no work permit"), NRP_NWP ("fully irregular status"). As outlined in Chap. 3, this categorical variable varies over time.

Other facets of the context of reception include: a time-varying categorical variable indicating the migrant's employment status (employed or unemployed, with inactive as the reference category); a time-varying dummy variable indicated the migrant's occupation, comparing entrepreneurial self-employment, noted in the literature as being conducive to Senegalese migrants" "transnational livelihood," to all other types of employment; a time-varying dichotomous variable measures selfreported economic status, with having the financial ability to cover basic needs being better than others in the same location compared to lesser self-reported status; and a time-varying count of family members or friends residing in the same country as the migrant captures potential effects of social networks. In addition to the above variables measuring the context of reception, dummy variables for residence in Italy and Spain in a given year (with France as the reference category) enter into the models to measure heterogeneity between these destinations not already captured by individual-level variables. 
Variables measuring years in destination, years of education, sex, and age capture individual characteristics expected to be associated with higher propensity to engage in transnational activities. Years in destination is measured as completed years since arrival at a particular year's destination, and this metric is "reset" for each subsequent stay in a different destination; the models include a quadratic term on years in destination to account for potential non-linearities in its effect. Years of education is measured as an interval variable. In order to avoid age-period-cohort collinearities with other variables, age at migration-which remains fixed over a given migration spell for an individual but then changes if the same individual migrates to another destination-enters the eq. A variable measuring number of previous migrations to Europe captures migration-specific human and social capital accumulated by an individual over multiple trips.

Research on Senegalese migration and transnationalism shows evidence of differential effects by ethnicity, so a dichotomous variable indicates Senegalese ethnic group: Wolof, with other ethnic groups (including Mandingue, Pular, Soninké, and other) as the reference category. ${ }^{1}$ Research has also shown that religion, especially membership in Islamic Sufi brotherhoods, plays an important role in structuring Senegalese transnationalism (Riccio 2001). The model thus includes a dummy for belonging to the Mouride brotherhood, with all other religious categories (including Tidiane, Layene, other Muslim, and not Muslim) as the reference group.

A set of time-varying indicators of the migrant's familial connections with individuals in Senegal measures affective links to the home community, including having a spouse in Senegal, having children in Senegal, and having at least one parent alive in Senegal. A dummy variable indicating family contributions to the financing of the migrant's trip (which can vary for each trip) captures instrumental or contractual relationships with the family that might be expected to structure some kinds of transnational activities (Chort et al. 2012). A variable indicating the migrant's identification of Dakar - far and away the country's most important urban area-as place of origin measures the different geographical zones corresponding to different migration streams from Senegal. A dummy for father's schooling (less than secondary school) measures the socioeconomic status of the sending family.

The dichotomous time-varying indicator for short returns was included in the model for the non-mobile transnational activities of remitting, investing, and HTA participation, allowing testing of hypotheses 3 and 4 .

To account for potential period effects on the propensity to engage in transnational activities, a dummy indicates arrival in the 1990 s or 2000 s, with arrivals prior to 1990 as the reference category. This choice of categories stems from the change in profile of Senegalese migrants in the 1990s, which corresponded to a change in social origins and destinations in Europe (Schoumaker et al. 2013).

\footnotetext{
${ }^{1}$ Qualitative research on Senegalese transnationalism has found that Senegalese in the new destination of Italy are extremely likely to participate in "transnational livelihoods" (Riccio 2008). As Senegalese in Italy tend to be from the Wolof ethnic group and adherents of the Mouride brotherhood, these modalities are tested as variables in the models.
} 


\subsubsection{Models}

Exploiting the longitudinal and time-varying nature of both outcome and explanatory variables requires methods that account for clustering of repeated observations of the same individual. Regular generalized linear models make the important assumption of conditional independence between observations. Such models, however, are unsuitable for data featuring repeated observations on the same individual, which are likely to violate the assumption of independence. ${ }^{2}$ Including a personspecific random intercept in the model, however, allows the dependence to be captured (Rabe-Hesketh and Skrondal 2008). This model can be written as

$$
\operatorname{logit}\left\{\operatorname{Pr}\left(y_{i t}=1 \mid \mathbf{x}_{i t}, \zeta_{i}\right)\right\}=\beta_{1}+\mathbf{x}_{i}^{\prime} \beta_{2}+\mathbf{x}_{i t}^{\prime} \beta_{3}+\zeta_{i}
$$

where $y_{i t}$ is the dichotomous outcome indicator of participation in a given transnational activity for person $i$ during year $t, \beta_{1}$ is a constant, $\mathbf{x}_{i}^{\prime}$ is a vector of timeconstant explanatory variables, $\mathbf{x}_{i t}^{\prime}$ is a vector of time-varying explanatory variables, $\beta_{2}$ and $\beta_{3}$ are regression coefficients, and $\zeta_{i}$ is the person-specific random intercept. All outcome and predictor variables are observed at time $t{ }^{3}$ The random intercept $\zeta_{i}$ is assumed to be independent across respondents $i$ and conditionally normally distributed with mean zero and variance $\psi$.

$$
\zeta_{i} \mid \mathbf{x}_{i t} \sim N(0, \psi)
$$

The person-specific random intercept induces the dependence between repeated observations, and can also be thought of as capturing unobserved heterogeneity in the propensity to engage in the outcome (Rabe-Hesketh and Skrondal 2008).

I estimate a random intercept model for each of my four outcome variables on the pooled three-country sample using adaptive Gauss-Hermite quadrature to approximate the likelihood function (Rabe-Hesketh and Skrondal 2008). Sensitivity tests indicated 48 quadrature points were appropriate for fitting the models accurately.

Dependence among the dichotomous responses for the same person can be summarized by the residual intraclass correlation $(\rho)$ of the underlying latent outcome variable given the explanatory variables:

\footnotetext{
${ }^{2}$ Models from previous chapters of this book either used dynamic survival models that do not violate assumptions of independence or selected cross-sectional samples of the data and thus did not need to account for repeated observations on the same individual. All models in previous chapters included corrections to standard errors to account for clustering arising from including multiple trips for individuals, but that clustering is a distinct phenomenon from the variety considered here.

${ }^{3}$ All models were also estimated with lagged predictors measured at time $t-1$ but results (not reported, available upon request) were substantively similar.
} 


$$
\rho=\frac{\psi}{\psi+\pi^{2} / 3}
$$

Intraclass correlation for dichotomous outcomes is expressed in terms of the latent responses because intraclass correlation for observed outcomes varies according to the values of the predictor variables. Rodríguez and Elo (2003) propose setting the observed predictors to the selected percentiles (such as the median) in order to allow for examination of this correlation for the manifest (observed) outcome. These measures of unobserved heterogeneity help quantify the extent to which individuals are prone to engage in transnational activities even after accounting for observed covariates. In the case of high intraclass correlation, it is possible that individuals have intrinsically high or low probabilities of engaging in certain transnational activities.

\subsubsection{Estimating Indirect Effects in a Non-linear Framework}

The caging hypothesis posits an indirect effect of legal statuses on non-mobile transnational activities via the mediating variable of short returns. Estimation of this indirect effect is straightforward in an ordinary least squares (OLS) model: the difference in the coefficients for the legal-status variables in models with (the "reduced model") and without (the "full model") the mediator variable (here, short returns) can be considered the indirect effect of that variable. In a non-linear framework, however, the underlying latent variable has a scale that is unknown and depends on the predictors included in the model. Calculating indirect effects in nonlinear models using techniques developed for linear regression thus conflates rescaling with mediation (Karlson and Holm 2011; Mood 2010).

Kohler, Karlson, and Holm propose a method (hereafter, "KHB method") for effect decomposition in a non-linear framework (Kohler et al. 2011). They propose extracting the information that is not contained in the predictor variable of interest from mediator by calculating the residuals of a regression of the mediator on the predictor variable of interest and using the residuals of this regression, which have the same standard deviation as the mediator variable itself and thus induce the same scale for the coefficients, in the reduced model. The KHB method allows the calculation of the indirect effects of legal statuses on non-mobile transnational activities as transmitted by the mediator variable of short visits to the homeland. 


\subsection{Results}

\subsubsection{Descriptive Results}

Descriptive results provide support for the first two hypotheses: migrants with irregular status return home less frequently, indicating that territorial confinement accompanies these irregular statuses; and migrants with irregular statuses participate less frequently in non-mobile transnational activities, indicating that their lack of secure legal status directly blocks them from cross-border action. Table 5.1 presents weighted ${ }^{4}$ descriptive statistics by legal status for the analytic sample under study. The outcome variables indicating transnational activities are represented by the proportion of person-years in which migrants engaged in each activity. These descriptive statistics indicate significant variation in the prevalence of each activity. On average, Senegalese migrants remit in about $72 \%$ of the person-years, while they engage in the other transnational activities much less frequently. Short returns occur in about $30 \%$ of person-years, migrants report owning assets in Senegal about $25 \%$ of the time, and they participate in HTAs in about $19 \%$ of person-years. In addition, this table indicates that there is significant variation in the prevalence of these activities across legal statuses, with $F$-statistics all significant at $p<0.001$.

Migrants with fully regular (RP_WP) legal status are the most likely to visit the homeland, remit, and invest, while migrants with fully irregular (NRP_NWP) status are the least likely to participate in all of the transnational activities. Those migrants with only work authorization (NRP_WP) are the most likely to participate in associations. Migrants with only residence authorization (RP_NWP) are less likely than migrants with either fully regular status or work-only authorization to engage in all transnational activities. This is even true for visits to the homeland: migrants with only a residence permit reports such visits less frequently than migrants with only a work permit, indicating that a residence permit in and of itself, which should grant the legal ability to circulate, is not sufficient for successful circulation. Indeed, migrants with both a residence and a work permit report short returns to Senegal in almost $39 \%$ of person-years, indicating that fully regular status is positively associated with visits home. The descriptive evidence supports the hypothesis that those migrants who make short returns home have a higher propensity to engage in nonmobile transnational activities. Figure 5.2 displays variation in transnational activities conditional on legal status. The figure suggests that migrants with fully regular legal status are more likely to participate in each transnational activity than migrants with fully regular legal status. In addition, in most cases, migrants with fully regular status are also more likely to participate in these activities than migrants with mixed statuses.

The descriptive statistics also support the hypothesis of an indirect effect of territorial confinement on remitting, investing, and HTA participation via the inhibi-

\footnotetext{
${ }^{4}$ Normalized sampling weights were applied to the data. See Schoumaker and Mezger (2013) for a description of the calculation and use of weights with the MAFE data.
} 
Table 5.1 Descriptive statistics for MAFE-Senegal sample, by legal status

\begin{tabular}{|c|c|c|c|c|c|c|c|c|c|c|}
\hline \multirow[b]{3}{*}{ Variable } & \multicolumn{8}{|c|}{ Legal status } & \multirow{2}{*}{\multicolumn{2}{|c|}{ Total }} \\
\hline & \multicolumn{2}{|c|}{$\begin{array}{l}\text { Fully } \\
\text { irregular }\end{array}$} & \multicolumn{2}{|c|}{$\begin{array}{l}\text { Mixed (no } \\
\text { RP) }\end{array}$} & \multicolumn{2}{|c|}{$\begin{array}{l}\text { Mixed (no } \\
\text { WP) }\end{array}$} & \multicolumn{2}{|c|}{\begin{tabular}{|l} 
Fully \\
regular
\end{tabular}} & & \\
\hline & Mean & SD & Mean & SD & Mean & SD & Mean & SD & Mean & SD \\
\hline Short returns & 0.04 & 0.21 & 0.23 & 0.42 & 0.20 & 0.40 & 0.39 & 0.49 & 0.30 & 0.46 \\
\hline Remitting to Senegal & 0.55 & 0.50 & 0.77 & 0.42 & 0.57 & 0.49 & 0.77 & 0.42 & 0.72 & 0.45 \\
\hline Asset ownership in Senegal & 0.10 & 0.29 & 0.24 & 0.43 & 0.22 & 0.41 & 0.29 & 0.45 & 0.24 & 0.43 \\
\hline HTA financial participation & 0.07 & 0.25 & 0.28 & 0.45 & 0.14 & 0.35 & 0.22 & 0.42 & 0.19 & 0.39 \\
\hline $\begin{array}{l}\text { Legal status: fully irregular } \\
\text { (NRP_NWP) }\end{array}$ & 1 & 0 & 0 & 0 & 0 & 0 & 0 & 0 & 0.17 & 0.38 \\
\hline $\begin{array}{l}\text { Legal } \\
\text { status: mixed (NRP_WP) }\end{array}$ & 0 & 0 & 1 & 0 & 0 & 0 & 0 & 0 & 0.039 & 0.19 \\
\hline $\begin{array}{l}\text { Legal } \\
\text { status: mixed (RP_NWP) }\end{array}$ & 0 & 0 & 0 & 0 & 1 & 0 & 0 & 0 & 0.099 & 0.30 \\
\hline $\begin{array}{l}\text { Legal status: fully regular } \\
\text { (RP_WP) }\end{array}$ & 0 & 0 & 0 & 0 & 0 & 0 & 1 & 0 & 0.69 & 0.46 \\
\hline Entry status: no visa & 0.47 & 0.50 & 0.11 & 0.32 & 0.49 & 0.50 & 0.41 & 0.49 & 0.41 & 0.49 \\
\hline Destination: France & 0.48 & 0.50 & 0.49 & 0.50 & 0.62 & 0.49 & 0.64 & 0.48 & 0.61 & 0.49 \\
\hline Destination: Spain & 0.23 & 0.42 & 0.10 & 0.30 & 0.082 & 0.27 & 0.14 & 0.35 & 0.15 & 0.35 \\
\hline Destination: Italy & 0.30 & 0.46 & 0.40 & 0.49 & 0.30 & 0.46 & 0.22 & 0.41 & 0.25 & 0.43 \\
\hline Years in destination & 4.03 & 3.64 & 8.25 & 6.93 & 8.85 & 8.06 & 11.1 & 8.37 & 9.56 & 8.13 \\
\hline Period of arrival: post-1990 & 0.73 & 0.45 & 0.51 & 0.50 & 0.51 & 0.50 & 0.47 & 0.50 & 0.52 & 0.50 \\
\hline $\begin{array}{l}\text { Age at start of current } \\
\text { migration spell }\end{array}$ & 27.1 & 7.88 & 26.7 & 5.60 & 27.8 & 6.69 & 26.8 & 6.83 & 26.9 & 6.97 \\
\hline Sex: Male & 0.70 & 0.46 & 0.80 & 0.40 & 0.63 & 0.48 & 0.71 & 0.46 & 0.70 & 0.46 \\
\hline Years of education & 8.46 & 5.84 & 7.74 & 6.24 & 8.86 & 7.14 & 9.60 & 6.17 & 9.27 & 6.25 \\
\hline Ethnicity: Wolof & 0.55 & 0.50 & 0.51 & 0.50 & 0.50 & 0.50 & 0.42 & 0.49 & 0.45 & 0.50 \\
\hline Religion: Mouride & 0.50 & 0.50 & 0.46 & 0.50 & 0.33 & 0.47 & 0.29 & 0.45 & 0.34 & 0.47 \\
\hline Unemployed & 0.05 & 0.22 & 0.03 & 0.16 & 0.015 & 0.12 & 0.025 & 0.16 & 0.03 & 0.17 \\
\hline Employed & 0.77 & 0.42 & 0.92 & 0.28 & 0.72 & 0.45 & 0.84 & 0.37 & 0.82 & 0.39 \\
\hline Inactive & 0.18 & 0.39 & 0.058 & 0.23 & 0.27 & 0.44 & 0.14 & 0.34 & 0.15 & 0.36 \\
\hline Occupation: self-employed & 0.26 & 0.44 & 0.20 & 0.40 & 0.16 & 0.37 & 0.08 & 0.27 & 0.12 & 0.33 \\
\hline $\begin{array}{l}\text { Self-reported economic } \\
\text { status: good }\end{array}$ & 0.12 & 0.33 & 0.05 & 0.22 & 0.06 & 0.23 & 0.07 & 0.25 & 0.08 & 0.26 \\
\hline $\begin{array}{l}\text { Number of contacts at } \\
\text { destination }\end{array}$ & 2.03 & 2.02 & 1.94 & 2.15 & 3.07 & 2.55 & 3.68 & 2.78 & 3.27 & 2.71 \\
\hline Number of trips & 1.57 & 0.82 & 1.29 & 0.73 & 1.56 & 0.95 & 1.43 & 0.96 & 1.46 & 0.93 \\
\hline $\begin{array}{l}\text { Does not speak language of } \\
\text { destination }\end{array}$ & 0.41 & 0.49 & 0.29 & 0.46 & 0.36 & 0.48 & 0.23 & 0.42 & 0.28 & 0.45 \\
\hline Kids in Senegal & 0.40 & 0.49 & 0.39 & 0.49 & 0.37 & 0.48 & 0.29 & 0.45 & 0.32 & 0.47 \\
\hline Spouse in Senegal & 0.39 & 0.49 & 0.42 & 0.49 & 0.32 & 0.47 & 0.32 & 0.47 & 0.34 & 0.47 \\
\hline $\begin{array}{l}\text { Geographic origin: from } \\
\text { Dakar }\end{array}$ & 0.31 & 0.46 & 0.26 & 0.44 & 0.28 & 0.45 & 0.28 & 0.45 & 0.28 & 0.45 \\
\hline $\begin{array}{l}\text { Father's ed.: less than } \\
\text { secondary school }\end{array}$ & 0.72 & 0.45 & 0.75 & 0.43 & 0.67 & 0.47 & 0.67 & 0.47 & 0.68 & 0.47 \\
\hline
\end{tabular}


Table 5.1 (continued)

\begin{tabular}{|c|c|c|c|c|c|c|c|c|c|c|}
\hline \multirow[b]{3}{*}{ Variable } & \multicolumn{8}{|c|}{ Legal status } & \multirow{2}{*}{\multicolumn{2}{|c|}{ Total }} \\
\hline & \multicolumn{2}{|c|}{$\begin{array}{l}\text { Fully } \\
\text { irregular }\end{array}$} & \multicolumn{2}{|c|}{$\begin{array}{l}\text { Mixed (no } \\
\text { RP) }\end{array}$} & \multicolumn{2}{|c|}{$\begin{array}{l}\text { Mixed (no } \\
\text { WP) }\end{array}$} & \multicolumn{2}{|c|}{$\begin{array}{l}\text { Fully } \\
\text { regular }\end{array}$} & & \\
\hline & Mean & SD & Mean & SD & Mean & SD & Mean & SD & Mean & SD \\
\hline Trip paid by family & 0.32 & 0.47 & 0.24 & 0.43 & 0.49 & 0.50 & 0.41 & 0.49 & 0.40 & 0.49 \\
\hline Plan to stay: definitive & 0.53 & 0.50 & 0.32 & 0.47 & 0.37 & 0.48 & 0.45 & 0.50 & 0.45 & 0.50 \\
\hline $\begin{array}{l}\text { Trip motivation: work/better } \\
\text { life }\end{array}$ & 0.62 & 0.49 & 0.76 & 0.43 & 0.42 & 0.49 & 0.56 & 0.50 & 0.56 & 0.50 \\
\hline $\begin{array}{l}\text { At least one parent alive in } \\
\text { Senegal }\end{array}$ & 0.86 & 0.35 & 0.91 & 0.29 & 0.89 & 0.32 & 0.77 & 0.42 & 0.80 & 0.40 \\
\hline $\mathrm{N}$ (person-years) & \multicolumn{2}{|l|}{1448} & \multicolumn{2}{|l|}{307} & \multicolumn{2}{|l|}{937} & \multicolumn{2}{|l|}{5496} & \multicolumn{2}{|l|}{8188} \\
\hline $\mathrm{N}$ (trips) & \multicolumn{10}{|l|}{768} \\
\hline
\end{tabular}

Source: MAFE-Senegal

Notes: Sampling probability weights applied

short returns

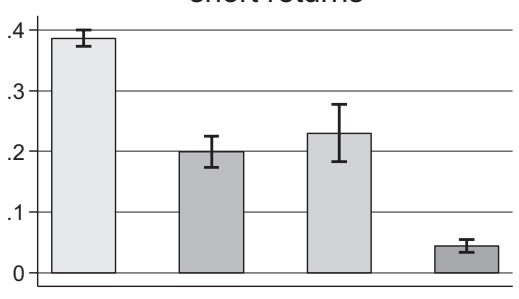

investing

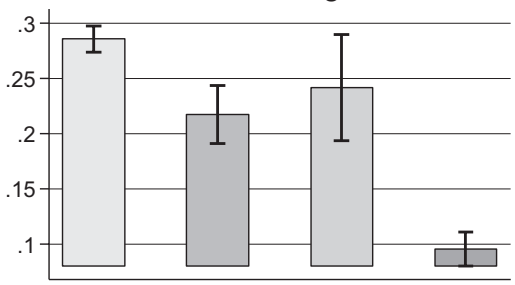

Fully regular

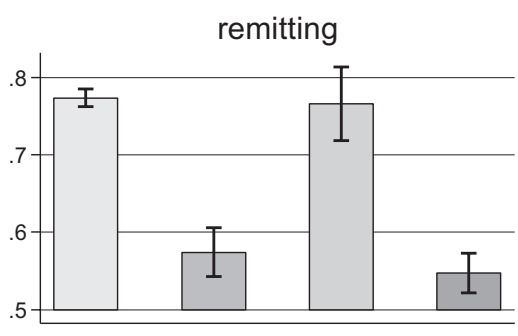

HTA participation

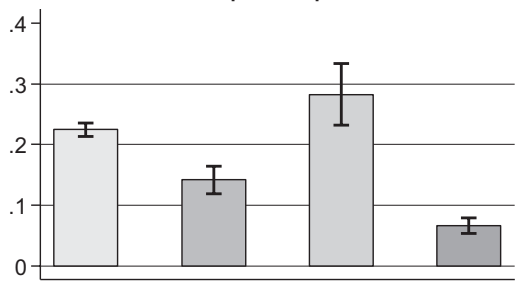

Mixed (no RP)

Fully irregular

Fig. 5.2 Average level of transnational activities, by legal status, with 95\% confidence intervals. (Source: MAFE-Senegal. Weighted data computed over person-years. 95\% confidence intervals displayed) 
tion of short returns. Figure 5.3 shows the variation in transnational activities conditional on both short returns legal status. Variation in non-mobile transnational activities by cross-border mobility is evident as in the previous figure: migrants who circulate are more likely to remit, invest, and participate in HTAs. In addition, this figure shows that legal status can operate through short returns to constrain nonmobile transnational activities: migrants who lack secure legal status and, as a result, do not visit the homeland engage in non-mobile transnational activities less frequently.

\subsubsection{Multivariate Results}

Table 5.2 displays results from the random-intercept logistic regression of each yearly transnational activity. In these multivariate models, results are displayed as average marginal effects (AMEs). While Chap. 3 outlines the rationale for presenting results as AMEs instead of logistic-regression coefficients or odds ratios, it is useful to review here some of their advantages. AMEs are useful for the interpretation of non-linear models and capture the expected change in the probability of the outcome associated with a one-unit or discrete change in a predictor variable (see Cameron and Trivedi 2010 for more information on average marginal effects).
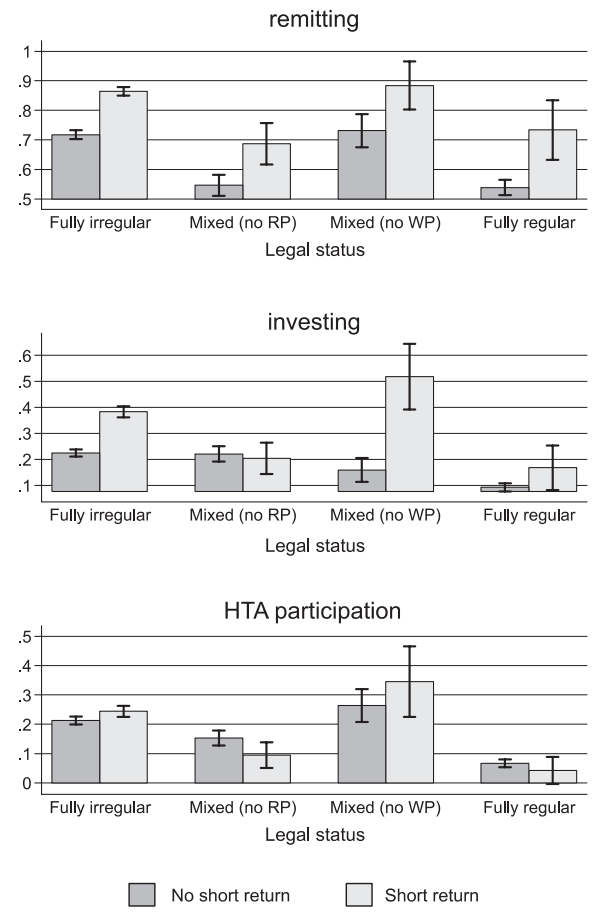

Fig. 5.3 Average level of transnational activities, by short return and legal status, with $95 \%$ confidence intervals. (Source: MAFE-Senegal. Weighted data computed over person-years. 95\% confidence intervals displayed) 


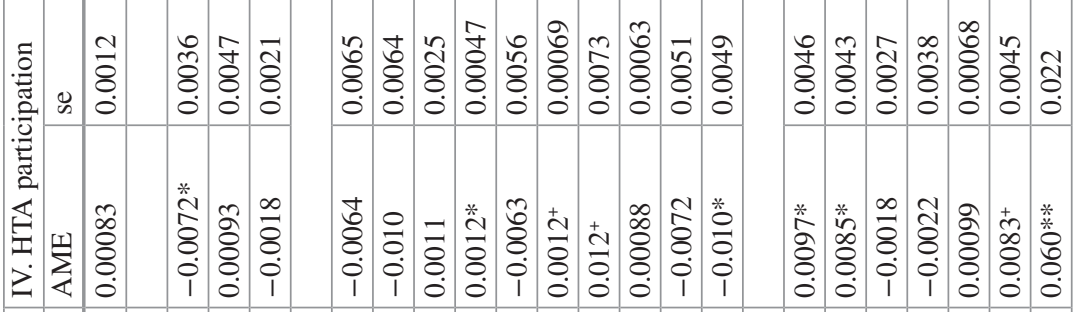

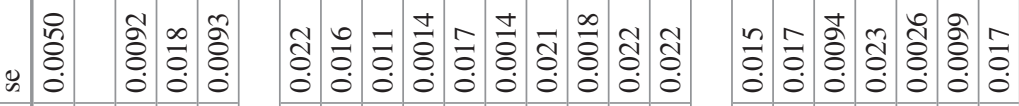
$\stackrel{\infty}{\Xi}$

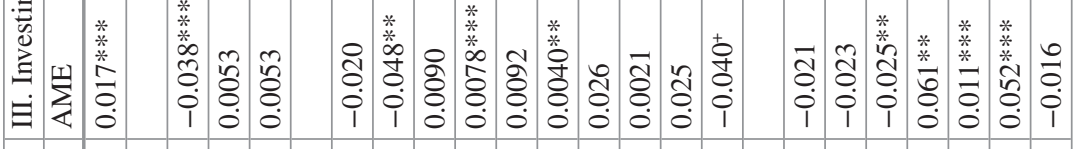

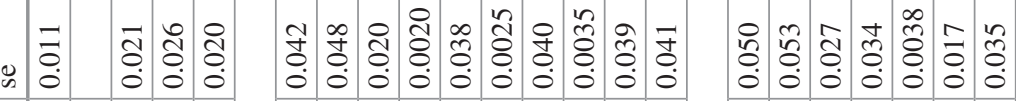

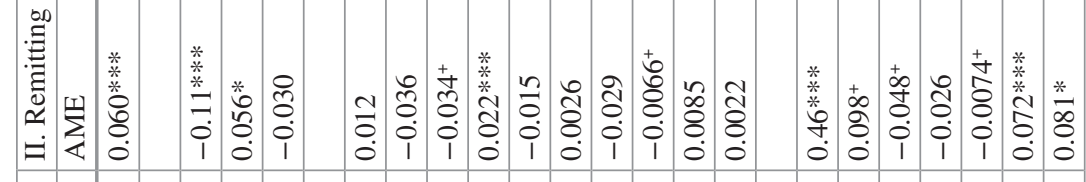

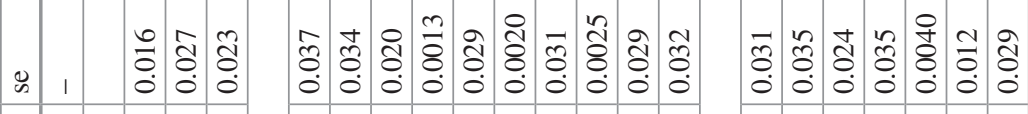
䒠

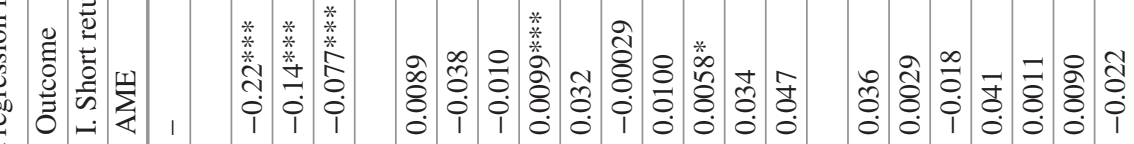

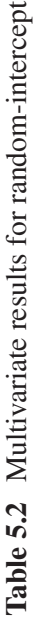

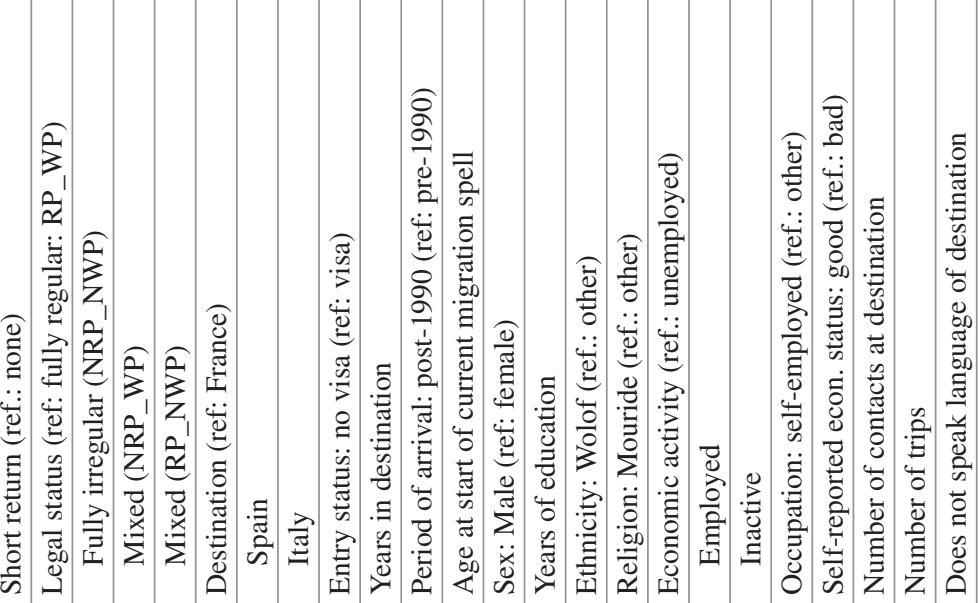




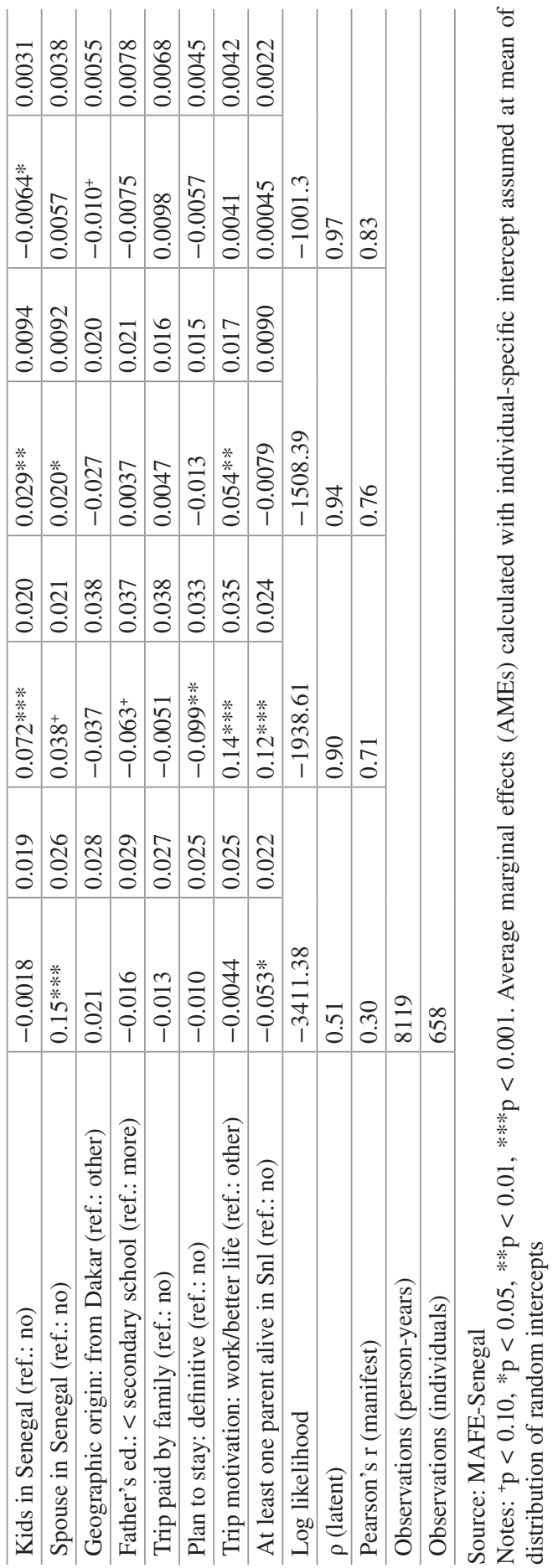


Mood (2010) argues that AMEs are appropriate for non-linear model comparisons, which is helpful when comparing the effect of a given variable across different models (the case of short returns here). For these random-effects models, AMEs are calculated assuming that the group-specific intercept is set at the mean of the distribution of the random intercepts (i.e., zero). It is also useful to note that the results are subject-specific probabilities, and not population-average probabilities: they refer to the yearly individual probability of engaging in each transnational activity.

Each model's residual intra-class correlation $(\rho)$ is also listed and is indicative of the degree to which the latent variable underlying each outcome is correlated across years for the same individual and can be interpreted in a way analogous to a Pearson correlation coefficient. Short returns has the lowest intra-class correlation at $\rho=0.51$, but the correlation at the level of the manifest outcome is lower, at 0.30; this indicates a fairly low within-person manifest correlation, with short returns on one occasion predicting $9 \%$ of the variability in short returns on a second occasion. Remitting and investing both have latent intraclass correlations of around 0.9, with lower manifest correlations of 0.71 for remitting and 0.76 for investing, indicating $\mathrm{R}^{2} \mathrm{~s}$ of 0.58 and 0.69 , respectively. HTA participation has the highest intra-class correlation at 0.97 , with a manifest correlation at the median of the predictors of 0.83 . This high correlation between yearly outcomes for this activity over time within individuals means that $69 \%$ of the variability in HTA participation is accounted for by previous participation. The within-subject dependence of transnational activities is thus much higher for remitting, investing, and HTA participation than for short returns. These intra-class correlations reinforce the importance of using a model that takes this high degree of within-individual clustering into account.

The following discussion of multivariate results will focus principally on the relationship between legal status and the probability of engaging in each of the four transnational activities in any given person-year. The base category for the composite legal-status variable is fully regular status, wherein migrants have both residence and work permits (RP_WP). The models also include a dichotomous variable for whether or not the migrant had a visa upon entry to the destination.

\section{Hypothesis 1: Territorial Confinement}

\section{Short Returns}

The descriptive results provided some measure of support for the hypothesis of territorial confinement: Senegalese migrants with fully regular (RP_WP) status are the most likely to make short visits home, while those migrants with irregular statuses, and especially migrants completely bereft of regular status, have a much lower likelihood of circulation. These results are overall averages, however, and do not take into account the clustered nature of the data nor the potential confounding effects of other predictors. Model I of Table 5.2 shows the results of the multivariate randomintercept logistic regression of yearly reports of short returns. 


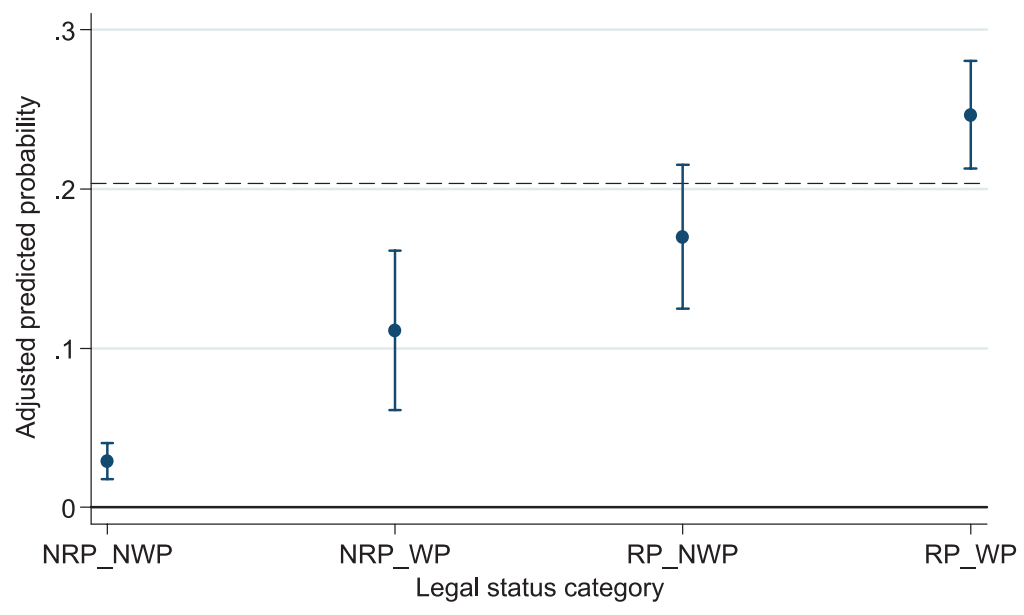

Fig. 5.4 Predicted probability of short return, by legal status category, with $95 \%$ confidence intervals (Dashed line represents grand mean of short returns)

These results indicate that the association between legal status and visiting the homeland is robust: compared to migrants with fully regular (RP_WP) status, those migrants with fully irregular or mixed statuses are statistically significantly less likely to circulate. Senegalese migrants with fully irregular (NRP_NWP) status are 22 percentage points less likely to report a visit to Senegal in any given year than migrants with fully regular (RP_WP) status. As Fig. 5.4 shows, this translates into a subject-specific predicted probability of circulation for migrants with fully irregular status of $3 \%$, while those migrants with both residence and work authorization have a subject-specific predicted probability of roughly $25 \%$; having fully regular status is thus associated with a seven-fold increase in the probability of making a visit home compared to having fully irregular status. Senegalese migrants who lack any kind of legal authorization have little chance of visiting the homeland because they are largely confined to the territory of the countries in which they reside.

Table 5.2 also indicates that migrants with semi-irregular or mixed statuses are also less likely than migrants with fully regular status to circulate between destination and origin. Lacking only a residence permit (NRP_WP) is associated with a 14-percentage-point gap in the probability of visiting the homeland compared to migrants with fully regular status, while lacking only a work permit (RP_NWP) is associated with an 8-point gap. Although Senegalese migrants with these mixed statuses have a higher predicted probability of circulating than migrants with fully irregular status, they still experience a degree of territorial confinement compared to migrants with fully regular status. Figure 5.4 shows that migrants with mixed status have a predicted probability of circulating of between $11 \%$ and $17 \%$. While yearly legal status clearly has a robust association with short returns, visa status at entry was not significantly associated with this outcome.

The model also indicates that there is no significant variation in the probability of short returns between destination countries, and additional models (not reported) 
failed to find a significant interaction between the legal-status and destination predictors. These multivariate results thus support the hypothesis of territorial confinement: Senegalese migrants who lack one or both forms of authorization are significantly less likely to engage in short returns to Senegal, and that this effect is constant across destinations. The legal reality that creates these irregular statuses thus functions as an important constraint on this physical, mobile form of crossborder action.

\section{Hypothesis 2: Blocked Transnationalism/Structural Exclusion}

Blocked transnationalism/structural exclusion was evident in the descriptive results: Senegalese migrants with fully regular (RP_WP) status were the most likely to engage in the non-mobile transnational activities of remitting, investing, and HTA participation, while migrants with fully or semi-irregular statuses were less likely to participate in these activities. This blockage as a result of lack of secure legal status is also evident in the multivariate results of Table 5.2.

\section{Remitting}

Model II of Table 5.2 shows the results of the random-intercept logistic regression of yearly reports of remitting. Compared to migrants with fully regular (RP_WP) status, those migrants with fully irregular (NRP_NWP) status are almost 10 percentage points less likely to report remitting in any given year. As Fig. 5.5 shows, this translates into a subject-specific predicted probability of remitting of $69 \%$ for

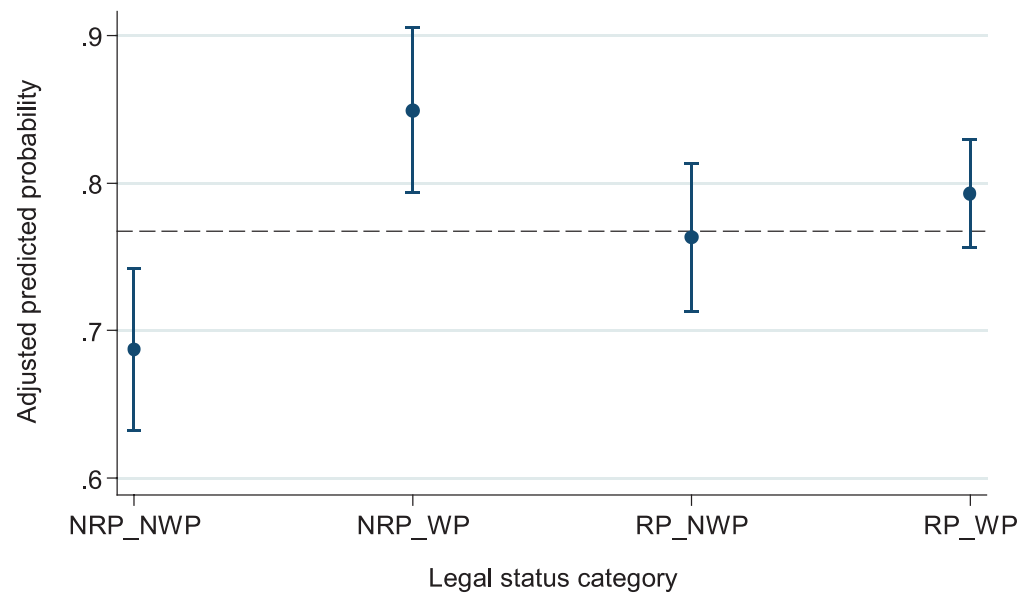

Fig. 5.5 Predicted probability of remitting by legal status category, with $95 \%$ confidence intervals (Dashed line represents grand mean of remitting) 
Senegalese migrants who lack both forms of authorization, compared to a predicted probability of almost $80 \%$ for migrants with fully regular status. Senegalese migrants who lack any form of legal authorization thus experience some kind of structural exclusion as a result of this status that is associated with a lower probability of remitting. It is worth noting, however, that the predicted probability is still relatively high even for migrants with fully irregular status, indicating a nearuniversality of remitting among Senegalese migrants and an ability to circumvent formal barriers to these transfers. In addition to the negative effect of yearly irregular status, having entered without a visa is also negatively associated with remitting (although only at $p<0.10$ ).

The story for the mixed/semi-irregular statuses is less clear. Compared to having both a residence and work permit (RP_WP), having a residence permit but not a work permit (RP_NWP) is negatively but not significantly associated with remitting, while having a work permit but not a residence permit (NRP_WP) is positively and significantly associated with remitting. Senegalese migrants with only a work permit have a predicted probability of remitting of approximately $85 \%$, making them the group most likely to send money to Senegal. Migrants experience this status quite infrequently (less than $4 \%$ of person-years), however, and most likely as a result of somewhat rare dysfunctions in the receiving states' immigration-control bureaucracies, or simply as the result of poor recall on the part of migrants. The legal reality thus seems to operate as a constraint only on those migrants who lack all forms of authorization instead of those with mixed statuses.

\section{Investing}

Model III of Table 5.2 displays the results from the random-intercept logistic regression of yearly reports of asset ownership in Senegal. These results confirm the negative descriptive association between fully irregular (NRP_NWP) status and investing: Senegalese migrants who lack both a residence permit and a work permit are almost 4 percentage points less likely to own assets in Senegal than those migrants with fully regular (RP_WP) status. Figure 5.6 shows that migrants with fully regular (RP_WP) status have a predicted probability of investing of $8.3 \% ; 50 \%$ lower than probability of investing for migrants with fully irregular status. Contrary to the results for short returns and remitting, however, there is no statistically significant difference between migrants with mixed/semi-irregular statuses and migrants with fully regular status in the probability of investing, nor does visa status at entry have an effect. The constraint of legal status thus blocks or excludes only those migrants with fully irregular status from owning assets in Senegal.

Interestingly, migrants in Italy are significantly less likely than those in France to invest, which is the only destination-specific variation evident in any of the models. This could be related to the preponderance of Mouride migrants in Italy, who may be more likely to donate money to religious endeavors (as is pointed out below, belonging to the Mouride brotherhood is also negatively associated with this outcome). 


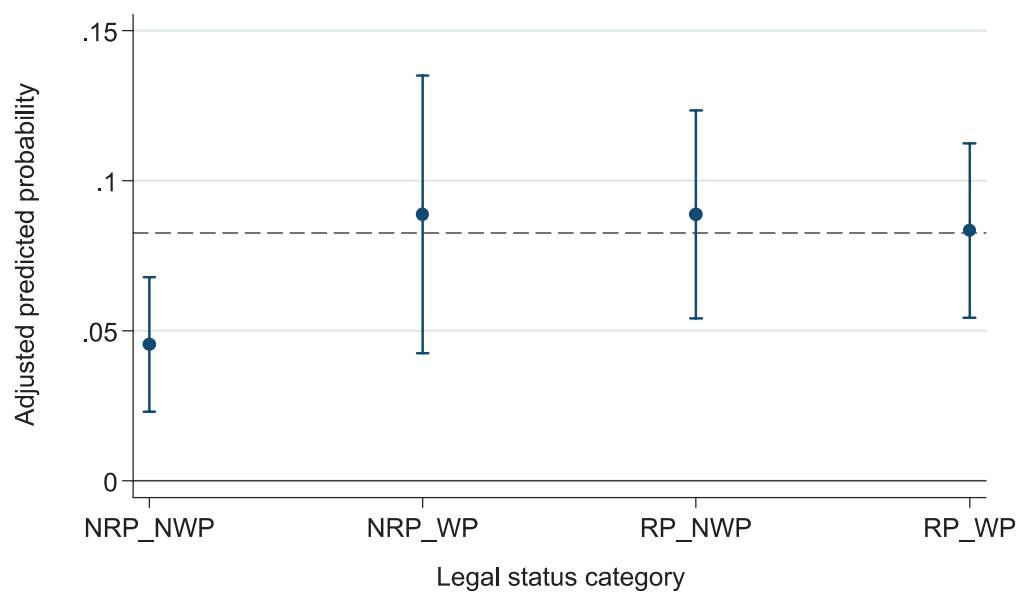

Fig. 5.6 Predicted probability of investing by legal status category, with $95 \%$ confidence intervals (Dashed line represents grand mean of investing)

\section{HTA Participation}

Descriptive statistics indicated that Senegalese migrants with fully irregular legal status are the least likely to make financial contributions to HTAs. Model IV of Table 5.2 supports this finding: migrants who lack both a residence permit and a work permit (NRP_NWP) are less likely than migrants with fully regular status to contribute to such associations. The difference in probabilities between these categories of migrants is small: migrants with fully irregular status are only 0.8 percentage points less likely to participate in these associations than migrants with fully regular status. Nonetheless, as Fig. 5.7 shows, even migrants with fully regular status have a subject-specific predicted probability of HTA participation of only about $2 \%$; migrants with fully irregular status are thus $40 \%$ less likely than migrants with fully regular status to participate in HTAs. Visa status at entry shows no association with HTA participation.

Findings from these multivariate models show that fully irregular legal status is consistently directly associated with a lower probability of engaging in the nonmobile cross-border activities of remitting, investing, and HTA participation among Senegalese migrants, while mixed/semi-irregular statuses do not have a consistent association with these outcomes. There is thus evidence that complete lack of authorization serves as some kind of a legal constraint on these transnational activities. As the activities in and of themselves do not directly depend on the physical crossing of a national border, direct territorial confinement is not an explanation for this negative association. 


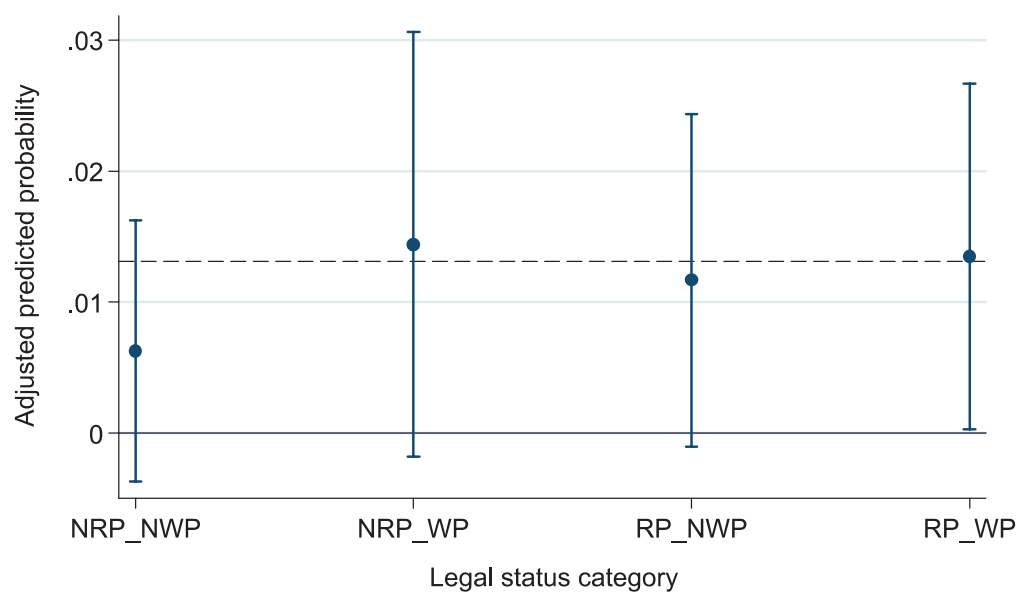

Fig. 5.7 Predicted probability of HTA participation by legal status category (Dashed line represents grand mean of HTA participation)

Just as lack of legal status prevents the legal crossing of borders, though, lack of legal status could prevent migrants from crossing other institutional boundaries that might be important for transnational engagement. Having fully irregular status might make migrants less likely to use formal financial services, which could limit their abilities to accumulate money and capital to repatriate as remittances or investments; they might also have fewer options for the actual transfer of funds or for accessing credit. Although it is clear that employment and good self-reported economic status are positively associated with these outcomes, these effects are net of the negative association with fully irregular status and thus do not mediate this effect.

Furthermore, Chap. 4 has shown that lack of legal status does not negatively affect male Senegalese migrants' probability of employment in these three countries; while employment per se is not limited by irregular status, irregularity may constrain Senegalese migrants' ability to participate in the formal labor market, thus increasing these migrants' precariousness. Older migrants with more time in the destination country also tend to be more likely to participate in these non-mobile transnational activities, and these are the very migrants who tend to possess a moresecure legal status. While it is clear that migrants with fully irregular status may be excluded from some institutions which may in turn facilitate cross-border action, their transnational activities may also be blocked by the uncertainty and precariousness that accompanies their lack of secure legal status. There is thus evidence that the legal reality constrains the transnational action of migrants with fully irregular status, but the mechanism of this legal constraint is still somewhat unclear. 


\section{Hypothesis 3: Maintenance of Affective Ties}

\section{Direct Effect of Short Returns on Non-mobile Transnational Activities}

The third hypothesis of this chapter is that visits to the homeland will promote other forms of non-mobile transnational activities through the maintenance of affective ties and the ability to gather first-hand information. The models for remitting, investing, and HTA participation thus include yearly short returns as a predictor, allowing examination of the direct effect of a visit home on these non-mobile activities. Models II, III, and IV in Table 5.2 display the direct effects of short visits to the homeland in the same year on each of the non-mobile outcomes. Returning to Senegal for a visit is associated with an increase of almost 6 percentage points in the probability of remitting and almost 2 percentage points in the probability of reporting asset ownership in Senegal. There is a positive association between short returns and participating in HTAs, but the effect is not statistically significant. These AMEs are displayed graphically in Fig. 5.8.

For two of the three non-mobile transnational activities, then, there is a positive direct relationship between visiting home and the probability of cross-border action. Both remitting and investing are financial decisions that migrants make in conjunction with their families: migrants decide whether to send money to family in Senegal or to invest capital in assets in Senegal in response to personal and collective desires. While other factors may influence these decisions (as we will examine below), they are fundamentally about allocation of resources in an extended family unit and are thus responsive to bonds of trust and emotion with the receivers of those resources.

Financial decisions are thus subject to first-hand ties and the ability to gather information: short visits to Senegal thus allow migrants to strengthen social ties and

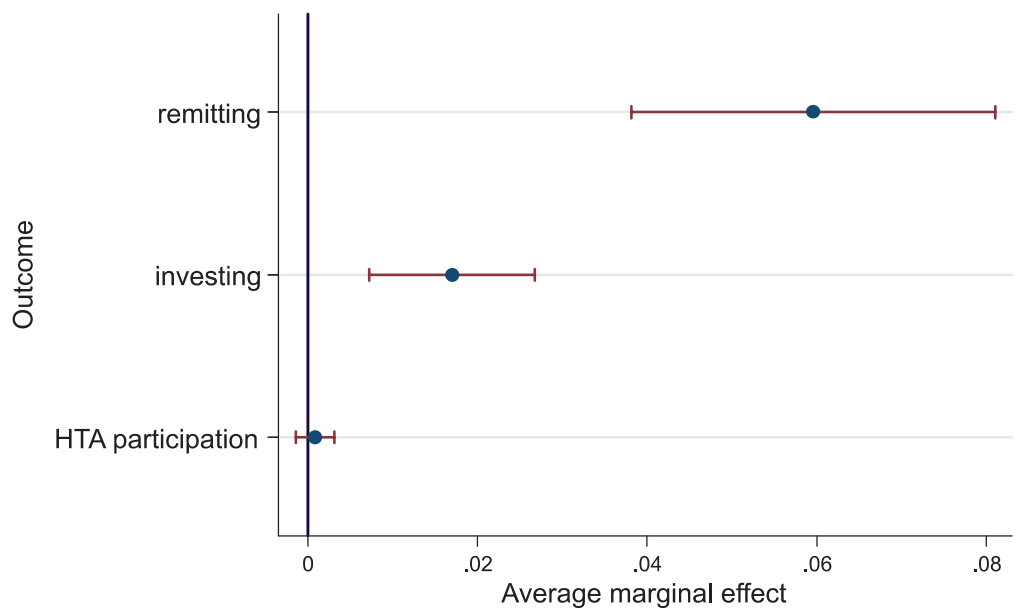

Fig. 5.8 Average marginal effects of short returns, by outcome, with $95 \%$ confidence intervals. (Source: MAFE-Senegal. Effects for short returns are net of other variables on each model) 
gather information about investment opportunities via physical presence. These visits may also allow the family at origin to more effectively extract resources from the migrant, as the contract-centered literature on remittances (Chort et al. 2012) might suggest. The same cannot be said about participation in HTAs, wherein a migrant makes a decision to participate financially but the association makes a collective decision about how to allocate those funds. This allocation decision is thus less sensitive to individual, personal visits to the homeland and the affective and socialtie-reinforcing co-presence that such visits produce.

\section{Direct Effect of Other Affective Ties (Spouse, Children, Other Family Ties)}

Other variables in the multivariate models (see Table 5.2) also demonstrate the importance of maintaining social and informational ties for both visits to the homeland and the non-mobile transnational activities. Having a spouse in Senegal is highly predictive of traveling there for a visit: such migrants are 15 percentage points more likely than migrants without a spouse in Senegal to travel there. Other kinds of family ties, however, were not predictive of increased mobility: migrants with children in Senegal showed no statistically significant difference in the likelihood of a short visit, while migrants with at least one parent alive in Senegal were actually 5.3 percentage points less likely than migrants without still-living parents to make a trip back. Family ties to individuals residing in Senegal are predictive of increased individual non-mobile transnational engagements. Senegalese migrants with a child in Senegal are 7.2 percentage points more likely to remit and 2.9 percentage points more likely to report owning assets in Senegal.

Having a spouse residing in Senegal was similarly positively associated with higher non-mobile transnational engagement: Senegalese migrants with a spouse in the homeland are 3.8 percentage points more likely to remit (although at $p<0.1$ ), and 2 percentage points more likely to own assets. In addition, having at least one parent alive in Senegal is associated with a 12-percentage-point increase in the probability of remitting. Active social ties to family in Senegal clearly promote individual economic non-mobile transnational activities.

In a by-now familiar pattern, HTA participation responds differently to these indicators of affective ties. Neither spouse nor living parent in Senegal has a significant association with HTA participation, while having a child in Senegal is negatively associated with participation in associations. Neither occasional physical co-presence in Senegal nor the residence of family members in Senegal is associated with collective cross-border activities. These results thus support the hypothesis that affective links with family members residing in the homeland encourage cross-border social action, but once again only for those financial activities that are responsive to these kinds of personal affective ties. 


\section{Direct Effect of Other Circulation-Related Variables}

Other variables also indicate the importance of circulating between destination and origin for ongoing non-mobile cross-border engagement. The number of trips is highly predictive of transnational activities: each additional prior trip is associated with a 7.2 percentage-point increase in the probability of remitting, a 5.2 percentagepoint increase in the probability of investing, and an almost 1 percentage-point increase in the probability of HTA participation. Repeat migration (approximately $30 \%$ of the sample reported more than one trip) thus reinforces the transnational social field in such a way as to make non-mobile transnational action more likely for both individual and collective activities.

Other indicators of a circular migration strategy are also related to remitting and investing. Migrants who reported planning to stay definitively in the destination country ( $46 \%$ of the sample) are 10 percentage points less likely to remit than those who do not plan to stay definitively, indicating that remitting is integral to Senegalese migrants' ability prepare an eventual return to Senegal. Migrants who reported having migrated principally for work or in search of a better life are 14 percentage points more likely to remit and 5.4 percentage points more likely to own assets in Senegal, suggesting that those migrants with a logic of accumulation are more likely to participate in these forms of financial cross-border action.

\section{Hypothesis 4: Caging and Indirect Effects of Legal Status Via Short Returns}

Results from the decomposition of direct effects indicate a significant negative indirect effect of fully irregular status on remitting and investing via the mediator of reduced short returns. While Table 5.2 displays the negative direct effects of irregular legal statuses and the positive direct effects of visits to the homeland on nonmobile transnational activities of Senegalese migrants, these models do not allow testing of the hypothesis of an indirect effect of irregular statuses on non-mobile activities via territorial confinement (see Fig. 5.1 for the theoretical model). Table 5.3 presents results from the non-linear decomposition of total effects using the KHB method and shows the direct, indirect, and total effects ${ }^{5}$ of irregular legal statuses on the non-mobile transnational activities of remitting, investing, and HTA participation.

Indirect effects of each of these statuses on the non-mobile activities run through the mediator of short returns. For remitting and investing, the indirect effect of fully irregular status (NRP_NWP) is negative and significant: 14\% of the total negative

\footnotetext{
${ }^{5}$ The effects are presented as logit coefficients (log-odds) so are not directly comparable to the quantities in Table 5.2. The direction and significance of the direct effects of legal status on each non-mobile transnational activity are the same as those presented in Table 5.2: there is a negative direct effect of fully irregular status on all three non-mobile activities, and a non-significant direct effect of the semi-irregular statuses on investing and HTA participation.
} 


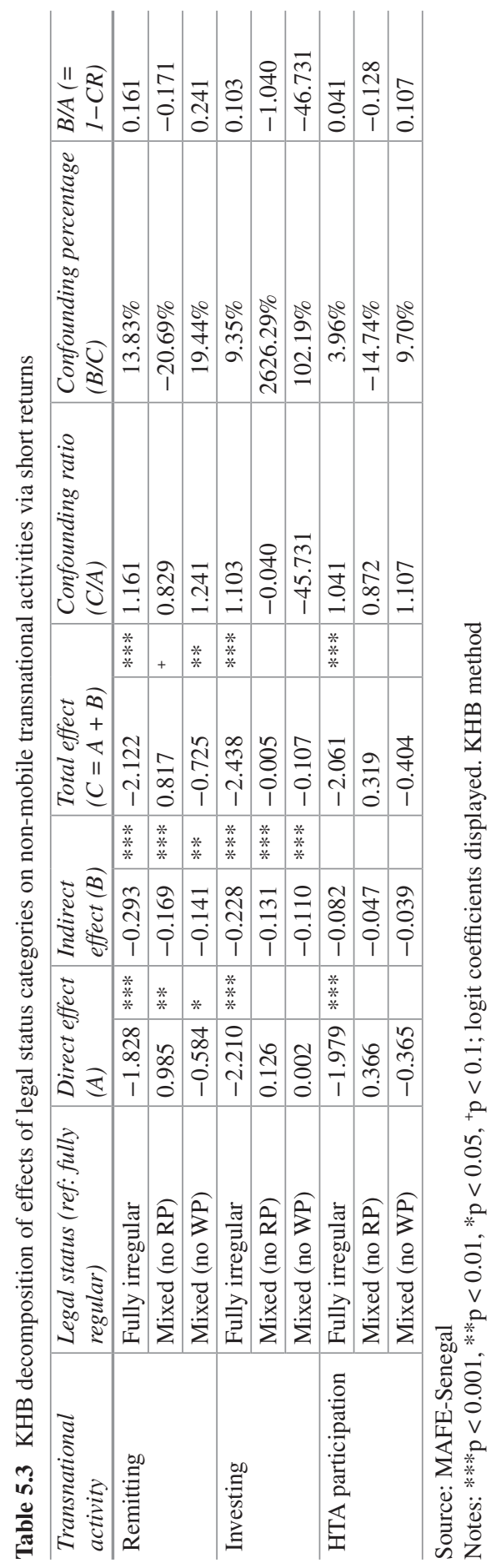


effect of legal status on remitting is due to short returns, while short visits to the homeland account for $9 \%$ of the total negative effect of legal status on investing. Thus, migrants with fully irregular (NRP_NWP) face not only a direct legal constraint from their irregular status but also an indirect negative constraint of their status via short returns: their irregular status directly reduces their ability to travel between destination and origin, and such visits encourage transnational engagement. The lack of ability to maintain and reinforce these social ties translates into reduced cross-border action. Irregular status serves to confine migrants to the territory of the destination, and thus cages their non-mobile transnational activities.

The pattern of indirect effects for the two mixed statuses reinforces the notion that territorial confinement is an indirect legal constraint even on individual nonmobile transnational activities. While the direct effects of these two semi-irregular statuses on remitting and investing is somewhat complicated, the pattern of indirect effects is unambiguously negative, indicating that the direct negative legal constraint of these mixed statuses on the ability to visit the homeland indirectly reduces the remitting and investing of Senegalese migrants who lack either a residence permit or a work permit.

The KHB method thus finds evidence to support the hypothesis of an indirect effect of territorial confinement on remitting and investing. The KHB method fails to find an indirect effect of fully irregular (NRP_NWP) or mixed statuses on HTA participation, which confirms the interpretation that this kind of collective cross-border activity is less sensitive to the maintenance of affective links afforded by in-person visits.

\subsection{Discussion}

Despite a celebration of the border-subverting nature of transnational activities, research on the role of the state suggests that the crossing of both geographic (Waldinger 2008) and institutional (Van Meeteren 2012) borders by migrants is subject to state control. One of the most pertinent forms of control for these types of border crossings is legal status: migrants who do not possess a secure form of legal status will find it more difficult to come and go physically across the destination state's borders and may also find it challenging to access other institutions that require formal state recognition and may help support cross-border engagement.

The results of this chapter unambiguously support the territorial confinement hypothesis: Senegalese migrants with fully irregular or mixed statuses were significantly less likely to make short returns to the homeland. These insecure legal statuses thus impose a direct constraint on Senegalese migrants' physical mobility. In Waldinger's (2008) territorial-confinement formulation, they are at the mercy of state immigration-control mechanisms for their ability to make trips back to the homeland. This finding is at odds with the portrayal of a globalized world in which movements are unfettered by borders, but is consistent with other research on globalization that sees some flows - capital, goods, and some kinds of workers-as 
freer than others-such as migrant labor (for the example of asymmetric flows in the NAFTA regime, see Massey et al. 2002).

The results of this chapter also support the hypothesis that migrants' transnational activities can be blocked by their lack of secure legal status and the exclusion from other formal institutions that ensues. Fully irregular status operated as a direct constraint on remitting, investing, and HTA participation for Senegalese migrants. It seems that this status may exclude these migrants from accessing other formal institutions that are, in some way, related to cross-border engagement. Lack of ability to open a bank account or apply for credit, both of which require documentation, might constrain migrants' transnational activities. While irregular status does not prevent Senegalese migrants from working, it certainly prevents them from working in the formal labor market and probably relegates them to insecure and poorly remunerated employment; this precarity that accompanies exclusion from the formal sector and its guarantees might decrease the ability and motivation to participate in transnational activities. These findings seem to be at odds with other literature on transnationalism that argues that cross-border action can be the result of exclusion and discrimination felt by migrants at destination (Itzigsohn and Saucedo 2002; Sana 2005); in the case of Senegalese migrants, the structural exclusion that accompanies irregularity of legal status seems to outweigh the reactive impulse.

Indeed, the results of these models indicate that Senegalese migrants may depend in some ways on the accumulation of resources for successful transnational engagement, at least for the individual financial activities of remitting and investing. Migrants who report being employed are 46 percentage-points more likely to report remitting in a given year than migrants who are unemployed, while reporting work/ search for a better life as the main motivation for having migrated is associated with a 14 percentage-point increase in the yearly probability of remitting. Migrants with good self-reported economic status are 6 percentage points more likely to own assets in Senegal, while those who report work or a better life as the motivation for their migration are 5.4 percentage points more likely to be investors.

This strategy of accumulation can be interpreted in light of the strong effects of short visits to the homeland and the affective ties that these visits foster. Making a visit to the homeland was associated with increased propensity to remit and invest: this form of mobility is thus of crucial importance in explaining these financial forms of non-mobile transnational activities. This is unsurprising given the assertions of the literature of physical co-presence, which has demonstrated that face-toface interaction is crucial in forging and feeding social ties and interpersonal trust (Urry 2002), but this is important determinant of action at a distance has been ignored in studies of transnational activities.

The direct effects of affective ties and other links to the homeland are also clear in the models: having children, a spouse, or parents in Senegal are associated with individual non-mobile transnational activities, as is repeat migration. All of these predictors indicate that ongoing links to the homeland are of paramount importance in structuring transnational engagement among Senegalese migrants. These findings thus reinforce the idea that building social status in Senegal in preparation for an eventual return is a principal motivation of Senegalese migrants (Kaag 2008; 
Kane 2011; Riccio 2008); Senegalese migrants may thus favor accumulation of resources as a way to finance their transnational engagement, perhaps even at the expense of pursuing integration in the destination society (Kaag 2008; van Nieuwenhuyze 2008).

In addition to examining the direct effect of visits to the homeland on longdistance transnational activities, this chapter found an indirect, negative effect of irregular legal statuses on these non-mobile activities transmitted through the inability to circulate between destination and origin. Migrants who have irregular status thus face three kinds of legal constraints on their cross-border actions: a direct legal constraint on their physical mobility, limiting short returns to Senegal; a direct legal constraint on their formal institutional participation, limiting their remitting, investing, and HTA participation; and an indirect legal constraint on their remitting and investing through their inability to visit home and the concomitant curtailing of social ties. Previous studies of transnational activities, in neglecting the relationship between visits home and non-mobile transnational activities, have thus neglected an important mechanism for the constraint that legal status may have on cross-border action.

The results of this chapter have also shown that not all transnational activities are subject to the same legal and social determinants. While fully irregular legal status was negatively directly associated with all four transnational activities, there were important differences among the other predictors. Semi-irregular legal statuses had a strong negative association with short returns, indicating that mobility is closely related to security of legal status. In turn, short returns along with variables indicating ongoing social and affective ties to Senegal were important predictors of both remitting and investing, both individual financial decisions likely to be influenced by sentiment and trust. This strong positive direct association was translated into a negative indirect association with semi-irregular status for these two financial activities through the constraint on border crossing, showing them to be sensitive to legal limitations on physical mobility.

HTA participation, on the other hand, is a collective activity and, as such, seems to be less responsive to physical co-presence in Senegal and affective ties to the homeland. Indeed, if there is any evidence of reactive transnationalism (Itzigsohn and Saucedo 2002), it may be with participation in these associations, as those migrants who do not speak the language of their destination are almost 6 percentage points more likely to report such participation. Legal exclusion does not motivate such reaction, but the HTA variable may not actually capture the full range of forms of participation in these associations as it only asks about financial contributions to them and not benefits from the social services to migrants in destination that such associations often provide. This study has thus shown that it is necessary to distinguish, in the Senegalese case, between affectively oriented and collective transnational activities, echoing Waldinger's (2008) assertion that transnational activities do not necessarily cluster together.

From a methodological perspective, the results of this chapter underline the importance of disaggregating traditional binary measures of legal status. For all of the transnational outcomes, there were differences between migrants with fully 
irregular status and those with mixed statuses that would have been erased by lumping them together as "irregular." Indeed, research has shown the empirical and conceptual value of a distinction between semi-compliant mixed statuses and fully irregular status (Ruhs and Anderson 2010), which this chapter's results underscore. At the same time, migrants' legal status upon entry, as measured by having a visa, had no association with transnational activities. Irregularity is thus complex, as Chap. 3 demonstrated, and this complexity needs to be taken into account when considering the constraints that this multifaceted legal reality places on migrants' actions.

\subsection{Conclusion}

Modern nation-states place contradictory demands on migrant's cross-border activities. On the one hand, many destination-country governments have started to recognize the role that migrants can and do play in the development of their homelands and have put in place "co-development" schemes (Kabbanji 2013; Weil 2002) to leverage transnational activities for the benefit of development programs. On the other hand, states have erected increasingly restrictive immigration-control apparatuses that make it difficult to acquire secure legal status. This difficulty translates into a captured loyalty among legal migrants, who have invested heavily in their membership, and a physical territorial confinement of those migrants who lack regular status. This control apparatus, coupled with a dominant ideology of assimilation that often looks askance at foreign loyalties, thus implicitly limits the cross-border activities of both documented and undocumented migrants.

The research literature on transnational activities has not grappled with these contradictions. Research on transnationalism has debated the novelty and social configurations of cross-border activities, but most studies do not consider the role that legal status plays in promoting or constraining them. This chapter suggests that territorial confinement, which results from lack of secure legal status produced by restrictive immigration-control apparatuses, not only directly constrains mobile transnational activities such as homeland visits but also indirectly reduces migrants' participation in non-mobile activities, such as remitting and investing. This chapter hypothesizes that the indirect relationship is mediated by short visits home, which nourish the affective social infrastructure that facilitates ongoing non-mobile, longdistance cross-border activities.

This chapter finds that legal status is an important predictor of transnational engagement, especially when the direct legal constraint on physical mobility is factored into other non-mobile forms of cross-border action. At the same time, the robustness of the social and affective infrastructure of most transnational activities indicates that legal status may constrain but does not completely determine crossborder action. While the state and formal institutions may demand "papers" for the crossing of some kinds of borders, migrants clearly find ways to circumvent these demands; this chapter shows that even migrants completely bereft of residence and 
work authorization have a non-zero probability of crossing the destination state's geographical border for a short visit to Senegal and continue to engage in other transnational activities. Indeed, research has shown that some Senegalese migrants may use non-mobile transnational activities such as remitting as a way to maintain affective ties with family in Senegal even without physical visits to the homeland (Hannaford 2016). At the same time, this chapter shows the importance of taking legal status into account as transnational activities are clearly subject to a number of legal constraints. This chapter demonstrates that it is crucial to consider multiple kinds of statuses: an approach that collapsed fully and semi-irregular statuses would have obscured the robust negative association between fully irregular status and all kinds of transnational activities.

The results of this chapter also allow a re-examination of the concept of a Senegalese "mode of migration" that is centered around "transnational livelihoods" (Riccio 2001, 2008). Qualitative literature has suggested that Senegalese migrants engage in an explicitly transnational form of migration, with Mouride traders in Italy depicted as the most likely to live their lives in Senegal and in Europe simultaneously. The ability to circulate between destination and origin is of key importance in this strategy, as it allows migrants to conduct entrepreneurial business across borders. This chapter, however, finds no effect of belonging to the Mouride brotherhood or of being self-employed in trading on the propensity of migrants to make short visits to Senegal net of legal status, affective ties, and the model's other variables. Indeed, belonging to the Mouride brotherhood is negatively associated with owning assets in Senegal, and being self-employed in trading is negatively associated with both remitting and investing. Living in Italy is likewise not associated with a transnational livelihood, and moreover had a negative effect on investing. Thus, a transnational lifestyle among Senegalese seems less associated with the cultural dispositions of certain religious and ethnic subgroups and more related to the interplay between the legal institutional structure that acts to constrain crossborder action and social infrastructure that drives these activities.

This study does lend credence, however, to the idea that the "homeland is the arena" (Kane 2011) in which social status matters for Senegalese migrants. There are strong effects of short visits, social ties, repeat migration, plans to return, and work-related motivation on non-mobile transnational activities. This shows that Senegalese migrants' cross-border engagement is largely motivated by a desire to return to Senegal eventually. A logic of accumulation at origin may thus dominate a logic of integration at destination (van Nieuwenhuyze 2008); both of these logics, however, are blocked by lack of secure legal status: migrants without "papers" are both directly blocked from transnational participation via legal exclusion from border crossing, and indirectly blocked by physical caging in the destination and the concomitant withering of social ties. Legal status is thus of key importance in keeping open the door to the homeland. 


\section{Appendices}

\section{Appendix A: Wording of Questions on Transnational Activities in MAFE-Senegal Questionnaire}

\begin{tabular}{l|l}
\hline $\begin{array}{l}\text { Transnational } \\
\text { activity }\end{array}$ & Question \\
\hline Short returns & $\begin{array}{l}\text { When you lived in [destination country], did you return to Senegal for a duration } \\
\text { of less than one year? In which year(s) did you return? }\end{array}$ \\
\hline Remittances & $\begin{array}{l}\text { Have there been periods of your life during which you regularly sent money to } \\
\text { someone who was in a country other than the one in which you lived? From } \\
\text { which year(s) to which year(s)? And in which country(ies) did the individual(s) } \\
\text { to whom you sent money live? }\end{array}$ \\
\hline Investments & $\begin{array}{l}\text { Now we will talk about the assets or businesses that you may have bought over } \\
\text { your lifetime, or that you may have received or inherited from somebody. Are } \\
\text { you CURRENTLY owner, in Senegal or elsewhere, of one or several plots of } \\
\text { land (agricultural land, building plot, or under construction); of one or several } \\
\text { house units (house, apartment...); of a business, venture, commercial premises } \\
\text { even on a rental basis (shop, workshop, taxis...)? And IN THE PAST, have you } \\
\text { been owner, in Senegal or elsewhere, of plots that you don't own anymore; of } \\
\text { house units that you don't own anymore; of a business, a venture, commercial } \\
\text { premises even on a rental basis that you don't own anymore? [then, for each } \\
\text { asset] in which country is this asset located? And how did you obtain this asset? }\end{array}$ \\
\hline Associations & $\begin{array}{l}\text { In the time that you spent abroad, were you at any time paying contributions or } \\
\text { membership fees to one or more associations (including religious organisations) } \\
\text { that finance projects in Senegal or support Senegalese migrants in Europe? From } \\
\text { which year(s) to which year(s)? }\end{array}$ \\
\hline
\end{tabular}

Source: MAFE-Senegal biographical questionnaire

\section{Appendix B: Raw Coefficient Estimates for Models from this Chapter}

\begin{tabular}{|c|c|c|c|c|}
\hline \multirow[b]{3}{*}{ Predictor } & \multicolumn{4}{|l|}{ Outcome } \\
\hline & $\begin{array}{l}\text { I. Short } \\
\text { returns }\end{array}$ & II. Remitting & III. Investing & \begin{tabular}{|l|} 
IV. HTA \\
participation
\end{tabular} \\
\hline & $\mathrm{B}(\mathrm{se})$ & $\mathrm{B}(\mathrm{se})$ & $\mathrm{B}(\mathrm{se})$ & $\mathrm{B}(\mathrm{se})$ \\
\hline Short return (ref.: none) & - & $0.90 * * *(5.52)$ & $0.67 * * *(4.00)$ & $0.16(0.77)$ \\
\hline \multicolumn{5}{|l|}{$\begin{array}{l}\text { Legal status (ref: fully } \\
\text { regular: RP_WP) }\end{array}$} \\
\hline $\begin{array}{l}\text { Fully } \\
\text { irregular (NRP_NWP) }\end{array}$ & $\begin{array}{l}-2.53 * * * \\
(-13.02)\end{array}$ & $\begin{array}{l}-1.39 * * * \\
(-5.53)\end{array}$ & $\begin{array}{l}-1.91 * * * \\
(-4.33)\end{array}$ & $\begin{array}{l}-2.04 * * * \\
(-4.33)\end{array}$ \\
\hline Mixed (NRP_WP) & $\begin{array}{l}-1.05 * * * \\
(-3.93)\end{array}$ & $0.96 *(2.01)$ & $0.21(0.30)$ & $0.17(0.21)$ \\
\hline Mixed (RP_NWP) & $\begin{array}{l}-0.52 * * \\
(-3.10)\end{array}$ & $-0.43(-1.58)$ & $0.20(0.58)$ & $-0.37(-0.90)$ \\
\hline
\end{tabular}




\begin{tabular}{|c|c|c|c|c|}
\hline \multirow[b]{3}{*}{ Predictor } & \multicolumn{4}{|l|}{ Outcome } \\
\hline & $\begin{array}{l}\text { I. Short } \\
\text { returns }\end{array}$ & II. Remitting & III. Investing & $\begin{array}{l}\text { IV. HTA } \\
\text { participation }\end{array}$ \\
\hline & B (se) & $\mathrm{B}(\mathrm{se})$ & B (se) & B (se) \\
\hline \multicolumn{5}{|l|}{ Destination (ref: France) } \\
\hline Spain & $0.06(0.24)$ & $0.17(0.28)$ & $-0.71(-0.91)$ & $-1.34(-1.06)$ \\
\hline Italy & $\begin{array}{l}-0.29 \\
(-1.11)\end{array}$ & $-0.51(-0.77)$ & $\begin{array}{l}-1.97 * * \\
(-3.05)\end{array}$ & $-2.97 * *(-2.58)$ \\
\hline $\begin{array}{l}\text { Entry status: no visa (ref: } \\
\text { visa) }\end{array}$ & \begin{tabular}{|l|}
-0.07 \\
$(-0.51)$
\end{tabular} & $-0.49^{+}(-1.72)$ & $0.36(0.83)$ & $0.22(0.46)$ \\
\hline Years in destination & \begin{tabular}{|l}
$0.15 * * *$ \\
$(8.55)$ \\
\end{tabular} & $\begin{array}{l}0.46^{* * * *} \\
(14.23)\end{array}$ & $\begin{array}{l}0.58 * * * \\
(14.11)\end{array}$ & $0.41 * * *(8.06)$ \\
\hline $\begin{array}{l}\text { Years in destination } \\
\text { squared }\end{array}$ & $\begin{array}{l}-0.00 * * * \\
(-6.95)\end{array}$ & $\begin{array}{l}-0.01 * * * \\
(-11.98)\end{array}$ & $\begin{array}{l}-0.01 * * * \\
(-7.86)\end{array}$ & $\begin{array}{l}-0.01 * * * \\
(-3.53)\end{array}$ \\
\hline $\begin{array}{l}\text { Period of arrival: post-1990 } \\
\text { (ref: pre-1990) }\end{array}$ & $0.23(1.06)$ & $-0.21(-0.38)$ & $0.37(0.54)$ & $-1.39(-1.50)$ \\
\hline $\begin{array}{l}\text { Age at start of current } \\
\text { migration spell }\end{array}$ & $\begin{array}{l}-0.00 \\
(-0.15)\end{array}$ & $0.04(1.08)$ & $0.16 * *(3.21)$ & $0.23 * * *(4.00)$ \\
\hline Sex: Male (ref: female) & $0.07(0.33)$ & $-0.43(-0.73)$ & $1.06(1.18)$ & $2.55 *(2.31)$ \\
\hline Years of education & $0.04 *(2.28)$ & $-0.10^{+}(-1.90)$ & $0.08(1.12)$ & $0.17^{+}(1.93)$ \\
\hline $\begin{array}{l}\text { Ethnicity: Wolof (ref.: } \\
\text { other) }\end{array}$ & $0.24(1.18)$ & $0.12(0.22)$ & $1.02(1.16)$ & $-1.88^{+}(-1.73)$ \\
\hline $\begin{array}{l}\text { Religion: Mouride (ref.: } \\
\text { other) }\end{array}$ & $0.33(1.51)$ & $0.03(0.05)$ & $-1.62^{+}(-1.74)$ & $-3.96 * *(-3.28)$ \\
\hline \multicolumn{5}{|l|}{$\begin{array}{l}\text { Economic activity (ref.: } \\
\text { unemployed) }\end{array}$} \\
\hline Employed & $0.27(1.09)$ & $\begin{array}{l}4.25 * * * \\
(10.28)\end{array}$ & $-0.76(-1.58)$ & $3.58 * * *(4.47)$ \\
\hline Inactive & $0.02(0.08)$ & $0.81^{+}(1.78)$ & $-0.84(-1.47)$ & $3.34 * * *(3.85)$ \\
\hline $\begin{array}{l}\text { Occupation: self-employed } \\
\text { (ref.: other) }\end{array}$ & $\begin{array}{l}-0.13 \\
(-0.72)\end{array}$ & $-0.67^{+}(-1.87)$ & $\begin{array}{l}-1.10^{* *} \\
(-2.58)\end{array}$ & $-0.38(-0.65)$ \\
\hline $\begin{array}{l}\text { Self-reported econ. status: } \\
\text { good (ref.: bad) }\end{array}$ & $0.28(1.20)$ & $-0.37(-0.79)$ & $1.96 * * *(3.38)$ & $-0.47(-0.54)$ \\
\hline $\begin{array}{l}\text { Number of contacts at } \\
\text { destination }\end{array}$ & $0.01(0.27)$ & $\begin{array}{l}-0.11^{*} \\
(-1.97)\end{array}$ & $0.43 * * *(4.91)$ & $0.19 *(2.15)$ \\
\hline Number of trips & $0.06(0.74)$ & $1.03 * * *(4.24)$ & $2.06 * * *(5.74)$ & $1.64 * * *(3.35)$ \\
\hline $\begin{array}{l}\text { Does not speak language of } \\
\text { destination }\end{array}$ & $\begin{array}{l}-0.16 \\
(-0.76)\end{array}$ & $1.22 *(2.30)$ & $-0.67(-0.94)$ & $6.50 * * *(6.42)$ \\
\hline Kids in Senegal (ref.: no) & $\begin{array}{l}-0.01 \\
(-0.09) \\
\end{array}$ & $1.07 * * *(3.65)$ & $1.09 * * *(3.35)$ & $-1.46 * *(-3.21)$ \\
\hline $\begin{array}{l}\text { Spouse in Senegal (ref.: } \\
\text { no) }\end{array}$ & \begin{tabular}{|l|}
$1.02 * * *$ \\
$(6.34)$
\end{tabular} & $0.56^{+}(1.82)$ & $0.78 *(2.34)$ & $0.98 *(2.21)$ \\
\hline $\begin{array}{l}\text { Geographic origin: from } \\
\text { Dakar (ref.: other) }\end{array}$ & $0.15(0.74)$ & $-0.53(-0.98)$ & $\begin{array}{l}-3.70 * * \\
(-3.29)\end{array}$ & $-3.70 * *(-3.29)$ \\
\hline
\end{tabular}




\begin{tabular}{|c|c|c|c|c|}
\hline \multirow[b]{3}{*}{ Predictor } & \multicolumn{4}{|l|}{ Outcome } \\
\hline & $\begin{array}{l}\text { I. Short } \\
\text { returns }\end{array}$ & II. Remitting & III. Investing & \begin{tabular}{|l|} 
IV. HTA \\
participation
\end{tabular} \\
\hline & B (se) & B (se) & B (se) & B (se) \\
\hline $\begin{array}{l}\text { Father's ed.: < secondary } \\
\text { school (ref.: more) }\end{array}$ & $\begin{array}{l}-0.12 \\
(-0.56) \\
\end{array}$ & $-0.95^{+}(-1.67)$ & $0.15(0.17)$ & $-1.28(-1.18)$ \\
\hline $\begin{array}{l}\text { Trip paid by family (ref.: } \\
\text { no) }\end{array}$ & $\begin{array}{l}-0.09 \\
(-0.46)\end{array}$ & $-0.07(-0.14)$ & $0.19(0.29)$ & $1.75^{+}(1.94)$ \\
\hline $\begin{array}{l}\text { Plan to stay: definitive } \\
\text { (ref.: no) }\end{array}$ & $\begin{array}{l}-0.07 \\
(-0.40)\end{array}$ & $\begin{array}{l}-1.41 * * \\
(-3.04)\end{array}$ & $-0.54(-0.90)$ & $-1.33(-1.49)$ \\
\hline $\begin{array}{l}\text { Trip motivation: work/ } \\
\text { better life (ref.: other) }\end{array}$ & $\begin{array}{l}-0.03 \\
(-0.17)\end{array}$ & $1.87 * * *(4.37)$ & $2.23 * * *(3.46)$ & $0.85(1.19)$ \\
\hline $\begin{array}{l}\text { At least one parent alive in } \\
\text { Snl (ref.: no) }\end{array}$ & $\begin{array}{l}-0.36^{*} \\
(-2.50)\end{array}$ & $1.61 * * *(5.60)$ & $-0.31(-0.90)$ & $0.09(0.21)$ \\
\hline Constant & $\begin{array}{l}-2.92 * * * \\
(-4.80)\end{array}$ & $\begin{array}{l}-5.76 * * * \\
(-4.13)\end{array}$ & $\begin{array}{l}-21.15 * * * \\
(-9.78)\end{array}$ & $\begin{array}{l}-28.40 * * * \\
(-10.55)\end{array}$ \\
\hline Observations & 8119 & 8119 & 8119 & 8119 \\
\hline AIC & 6884.76 & 3941.22 & 2066.6 & \begin{tabular}{|l|}
3080.79 \\
\end{tabular} \\
\hline $\mathrm{BIC}$ & 7101.82 & 4156.28 & 2290.66 & 3304.85 \\
\hline Log likelihood & -3411.38 & -1938.61 & -1001.3 & -1508.39 \\
\hline$\chi^{2}$ & 493.55 & 637.36 & 567.16 & 305.85 \\
\hline Degrees of freedom & 29 & 30 & 30 & 30 \\
\hline$\rho$ & 0.51 & 0.90 & 0.94 & 0.97 \\
\hline$\sigma_{U}$ & 1.86 & 5.52 & 7.25 & 10.91 \\
\hline
\end{tabular}

Source: MAFE-Senegal. t statistics in parentheses. ${ }^{+} \mathrm{p}<0.10,{ }^{*} \mathrm{p}<0.05,{ }^{*} \mathrm{p}<0.01, * * * \mathrm{p}<0.001$. Random-intercept logistic regression coefficients

\section{References}

Beauchemin, C., Caarls, K., \& Mazzucato, V. (2013). Senegalese migrants between here and there: An overview of family patterns. MAFE Working Papers (MAFE Working Paper 33). Paris: INED.

Bloch, A. (2008). Zimbabweans in Britain: Transnational activities and capabilities. Journal of Ethnic \& Migration Studies, 34(2), 287-305.

Boccagni, P. (2012a). Rethinking transnational studies: Transnational ties and the transnationalism of everyday life. European Journal of Social Theory, 15(1), 117-132.

Boccagni, P. (2012b). Revisiting the 'transnational' in migration studies: A sociological understanding. Revue Européenne Des Migrations Internationales, 28(1), 33-50.

Cameron, A. C., \& Trivedi, P. K. (2010). Microeconometrics using stata (Revised ed.). College Station: StataCorp LP.

Carling, J. (2007). Migration control and migrant fatalities at the Spanish-African borders. The International Migration Review, 41(2), 316.

Chort, I., Gubert, F., \& Senne, J.-N. (2012). Migrant networks as a basis for social control: Remittance incentives among Senegalese in France and Italy. Regional Science and Urban Economics, 42(5), 858-874.

Cisse, F. (2011). Senegal. In S. Mohapatra \& D. Ratha (Eds.), Remittance markets in Africa. Washington, D.C.: World Bank Publications. 
Diminescu, D. (2008). The connected migrant: An epistemological manifesto. Social Science Information, 47(4), 565-579.

Diop, M. (1993). L'immigration Ouest-Africaine En Europe. Études Internationales, 24(1), $111-124$.

Foner, N. (1997). What's new about transnationalism?: New York immigrants today and at the turn of the century. Diaspora: A Journal of Transnational Studies, 6(3), 355-375.

Freeman, G. P. (1995). Modes of immigration politics in liberal democratic states. International Migration Review, 29(4), 881-902.

Grillo, R., \& Riccio, B. (2004). Translocal development: Italy-Senegal. Population, Space and Place, 10(2), 99-111.

Guarnizo, L. E. (2003). The economics of transnational living. International Migration Review, 37(3), 666-699.

Guarnizo, L. E., Portes, A., \& Haller, W. (2003). Assimilation and transnationalism: Determinants of transnational political action among contemporary migrants. American Journal of Sociology, 108(6), 1211-1248.

Hannaford, D. (2016). Intimate remittances: Marriage, migration, and moneygram in Senegal. Africa Today, 62(3), 93-109.

Hannaford, D. (2017). Marriage without borders: Transnational spouses in neoliberal Senegal. Philadelphia: University of Pennsylvania Press.

Itzigsohn, J., \& Saucedo, S. G. (2002). Immigrant incorporation and sociocultural transnationalism. International Migration Review, 36(3), 766-798.

Kaag, M. (2008). Mouride transnational livelihoods at the margins of a European society: The case of residence Prealpino, Brescia, Italy. Journal of Ethnic \& Migration Studies, 34(2), 271-285.

Kabbanji, L. (2013). Towards a global agenda on migration and development? Evidence from Senegal. Population, Space and Place, 19(4), 415-429.

Kane, O. (2011). The homeland is the Arena: Religion, transnationalism, and the integration of Senegalese immigrants in America. Oxford: Oxford University Press.

Karlson, K. B., \& Holm, A. (2011). Decomposing primary and secondary effects: A new decomposition method. Research in Social Stratification and Mobility, 29(2), 221-237.

Kohler, U., Karlson, K. B., \& Holm, A. (2011). Comparing coefficients of nested nonlinear probability models. Stata Journal, 11(3), 420-438.

Kothari, U. (2008). Global peddlers and local networks: Migrant cosmopolitanisms. Environment and Planning D: Society and Space, 26, 500-516.

Landolt, P., Autler, L., \& Baires, S. (1999). From Hermano Lejano to Hermano Mayor: The Dialectics of Salvadoran Transnationalism. Ethnic and Racial Studies, 22(2), 290.

Levitt, P., \& Jaworsky, B. N. (2007). Transnational migration studies: Past developments and future trends. Annual Review of Sociology, 33(1), 129-156.

Massey, D. S. (2007). Categorically unequal: The American stratification system. New York: Russell Sage Foundation.

Massey, D. S., Durand, J., \& Malone, N. J. (2002). Beyond smoke and mirrors: Mexican immigration in an era of economic integration. New York: Russell Sage Foundation.

Mazzucato, V. (2008). The double engagement: Transnationalism and integration. Ghanaian migrants' lives between Ghana and The Netherlands. Journal of Ethnic and Migration Studies, 34(2), 199.

Mood, C. (2010). Logistic regression: Why we cannot do what we think we can do, and what we can do about it. European Sociological Review, 26(1), 67-82.

Mountz, A., Wright, R., Miyares, I., \& Bailey, A. J. (2002). Lives in limbo: Temporary protected status and immigrant identities. Global Networks, 2(4), 335-356.

Portes, A. (2010a). Economic sociology: A systematic inquiry. Princeton: Princeton University Press.

Portes, A., \& Rumbaut, R. (2006). Immigrant America: A portrait (3rd ed., rev.expanded, and update). Berkeley: University of California Press. 
Portes, A., \& Zhou, M. (2012). Transnationalism and development: Mexican and Chinese immigrant organizations in the United States. Population and Development Review, 38(2), 191-220.

Portes, A., Guarnizo, L. E., \& Landolt, P. (1999). The study of transnationalism: Pitfalls and promise of an emergent research field. Ethnic and Racial Studies, 22(2), 217.

Portes, A., Guarnizo, L. E., \& Haller, W. J. (2002). Transnational entrepreneurs: An alternative form of immigrant economic adaptation. American Sociological Review, 67(2), 278-298.

Rabe-Hesketh, S., \& Skrondal, A. (2008). Multilevel and longitudinal modeling using stata (2nd ed.). College Station: Stata Press.

Riccio, B. (2001). From 'ethnic group' to 'transnational community'? Senegalese migrants' ambivalent experiences and multiple trajectories. Journal of Ethnic and Migration Studies, 27, 583-599.

Riccio, B. (2008). West African transnationalisms compared: Ghanaians and Senegalese in Italy. Journal of Ethnic \& Migration Studies, 34(2), 217-234.

Rodríguez, G., \& Elo, I. (2003). Intra-class correlation in random-effects models for binary data. Stata Journal, 3(1), 32-46.

Ruhs, M., \& Anderson, B. (2010). Semi-compliance and illegality in migrant labour markets: An analysis of migrants, employers and the state in the UK. Population, Space and Place, 16(3), 195-211.

Sana, M. (2005). Buying membership in the transnational community: Migrant remittances, social status, and assimilation. Population Research and Policy Review, 24(3), 231-261.

Schiller, G., Nina, L. B., \& Blanc, C. S. (1995). From immigrant to transmigrant: Theorizing transnational migration. Anthropological Quarterly, 68(1), 48-63.

Schoumaker, B., \& Mezger, C. (2013). Sampling and computation weights in the MAFE surveys. 6. Institut national d'études démographiques.

Schoumaker, B., Flahaux, M.-L., Schans, D., Beauchemin, C., Mazzucato, V., \& Sakho, P. (2013). Changing patterns of African migration: A comparative analysis. MAFE Working Paper 18 (Vol. 18). Paris: INED.

Sciortino, G. (2004). Between phantoms and necessary evils. Some critical points in the study of irregular migrations to Western Europe. In A. Böcker, B. de Hart, \& I. Michalowski (Eds.), IMIS-beiträge: Migration and the regulation of social integration. Osnabrück: Institut für Migrationsforschung und Interkulturelle Studien (IMIS).

Smith, R. C. (2006). Mexican New York: Transnational lives of new immigrants. Berkeley: University of California Press.

Spire, A. (2005). Etrangers à la carte: L'administration de l'immigration en France (1945-1975). Paris: Grasset.

Tall, S. M. (2008a). La Migration International Sénégalaise: Des Recrutements de Main-d'oeuvre Aux Pirogues. In M.-C. Diop (Ed.), Le Sénégal Des Migrations: Mobilités, Identités Et Sociétés, Hommes et sociétés (pp. 37-67). Paris: Karthala.

Timera, M. (1997). L'immigration Africaine En France: Regards Des Autres et Repli Sur Soi: La France et Les Migrants Africains= The African immigration in France: The withdrawal of the other: France and the African migrants. Politique Africaine, 67, 41-47.

Urry, J. (2002). Mobility and proximity. Sociology, 36(2), 255-274.

Van Meeteren, M. (2012). Transnational activities and aspirations of irregular migrants in Belgium and the Netherlands. Global Networks, 12(3), 314-332.

van Nieuwenhuyze, I. (2008). Getting by in Europe's urban labour markets: Senegambian migrants' strategies for survival, Documentation and Mobility. Amsterdam: Amsterdam University Press.

Vertovec, S. (2003). Migration and other modes of transnationalism: Towards conceptual crossfertilization. International Migration Review, 37(3), 641-665.

Waldinger, R. (2008). Between 'here' and 'there': Immigrant cross-border activities and loyalties. International Migration Review, 42(1), 3-29.

Waldinger, R., \& Fitzgerald, D. (2004). Transnationalism in question. American Journal of Sociology, 109(5), 1177-1195. 
Weil, P. (2002). Towards a coherent policy of co-development. International Migration, 40(3), 41-55.

World Bank Group. (2016). Migration and remittances factbook 2016 (3rd ed.). Washington, DC: World Bank.

World Bank Group. (2017). Annual remittances data, inflows. Washington, D.C.: World Bank.

Zolberg. (1999). Matters of state: Theorizing immigration policy. In C. Hirschman, J. DeWind, \& P. Kasinitz (Eds.), The handbook of international migration: The American experience (pp. 71-92). New York: Russell Sage Foundation.

Open Access This chapter is licensed under the terms of the Creative Commons Attribution 4.0 International License (http://creativecommons.org/licenses/by/4.0/), which permits use, sharing, adaptation, distribution and reproduction in any medium or format, as long as you give appropriate credit to the original author(s) and the source, provide a link to the Creative Commons licence and indicate if changes were made.

The images or other third party material in this chapter are included in the chapter's Creative Commons licence, unless indicated otherwise in a credit line to the material. If material is not included in the chapter's Creative Commons licence and your intended use is not permitted by statutory regulation or exceeds the permitted use, you will need to obtain permission directly from the copyright holder.

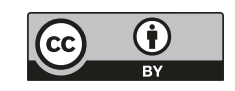

